$11-2020$

\title{
Does Knowledge from Home Markets Boost Outward Foreign Direct Investments of Emerging Economy Multinationals? Evidence from Indian Family EMNEs
}

Arindam Mondal

XLRI - Xavier School of Management, Jamshedpur, INDIA

Sarada Devi Gadepalli

Manchester Institute of Innovation Research, Alliance Manchester Business School, University of Manchester, UK

\section{Recommended Citation}

Mondal, Arindam and Gadepalli, Sarada Devi (2020) "Does Knowledge from Home Markets Boost Outward Foreign Direct Investments of Emerging Economy Multinationals? Evidence from Indian Family EMNEs," American Business Review. Vol. 23 : No. 2 , Article 2.

DOI: 10.37625/abr.23.2.211-240

Available at: https://digitalcommons.newhaven.edu/americanbusinessreview/vol23/iss2/2 
Does Knowledge from Home Markets Boost Outward Foreign Direct Investments of Emerging Economy Multinationals? Evidence from Indian Family EMNEs

\section{Cover Page Footnote}

An earlier version of this paper has been selected for the 2020 HKUST Best Paper for Global Strategy

Finalist Award at the Academy of Management Annual Conference, 2020. 


\title{
Does Knowledge from Home Markets Boost Outward Foreign Direct Investments of Emerging Economy Multinationals? Evidence from Indian Family EMNEs
}

\author{
Arindam Mondal ${ }^{a}$ and Sarada Devi Gadepalli ${ }^{b}$ \\ https://doi.org/10.37625/abr.23.2.211-240
}

\begin{abstract}
Despite increasing research on multinationals from emerging economies (EMNEs), our understanding of the antecedents of their international expansion is still limited. In this study, we seek to examine whether knowledge gained from operating in their complex and diverse domestic markets deter or aid the outward foreign direct investments of EMNEs. As family firms are dominant in emerging economies, we further explore how heterogeneity within family firms moderate this relationship. We conduct our investigations using a proprietary longitudinal dataset comprising 213 EMNEs from India featuring in the S\&P Bombay Stock Exchange (BSE) 500 index covering a six-year period from 2007-08 to 2012-13, of which 175 were family EMNEs and find supporting evidence for our theoretical predictions.
\end{abstract}

\section{KEYWORDS}

Internationalization, Diversification, Family Firm, Socioemotional Wealth, Business Groups, Emerging Economy, Knowledge Based View

\section{INTRODUCTION}

Since the last decade, emerging market multinationals (EMNEs) have been accounting for a significant share of global outward foreign direct investments (OFDI) with family-owned enterprises constituting a vast majority of the EMNEs (Ray et al., 2018; De Massis et al., 2018; Stoian and Mohr, 2016). In 2014, OFDI from developing and transition economies accounted for approximately $40 \%$ of global FDI volume (UNCTAD, 2016). The total OFDI stock CAGR growth, in emerging economies, in the period, 2010-2018 is $10.72 \%$ (UNCTAD, 2019). Given that family businesses constitute two-thirds of all businesses worldwide, family businesses have a major role in the growth of OFDI from emerging economies (Family Firm Institute, 2017).

One of the prominent examples of foreign investments by emerging market firms is the Lenovo acquisition of IBM x86 server business in 2014-2015, for approximately $\$ 2.1$ billion (Lenovo, 2014). The Tata group, a leading family business group in India, has invested around $\$ 20$ billion in acquisitions of foreign companies and earns about three-fifths of its revenue from foreign sales (The Economist, 2011).

a XLRI - Xavier School of Management, Jamshedpur, INDIA, Email: arindammondal@xlri.ac.in

b Manchester Institute of Innovation Research, Alliance Manchester Business School, University of Manchester, UK, Email: sarada.gadepalli@manchester.ac.uk

An earlier version of this paper has been selected for the 2020 HKUST Best Paper for Global Strategy Finalist Award at the Academy of Management Annual Conference, 2020.

Corresponding Author:

Gadepalli (sarada.gadepalli@manchester.ac.uk) 
The TCC group of Thailand, acquired F\&N's soft drinks, dairy, and publishing businesses for $\$ 11.2$ billion (Reuters, 2013). Such widespread investments pose a conundrum to the international business and family business scholars alike. EMNEs, in general, are considered to lack critical ownership related advantages while being plagued with negative 'country of origin' effects (Ray et al., 2018; Baskaran et al., 2017; Stoian and Mohr, 2016; Narula and Kodiyat, 2016; Deng, 2013; Madhok and Keyhani, 2012). Moreover, since OFDI requires significant resource commitments and takes years to generate steady profits, it is even more challenging for typically resource-constrained family EMNEs (Hu and Cui, 2014; Bhaumik et al., 2010). Consequently, insights into the antecedents of their international expansion and its contingencies are critical for understanding the survival and future growth of family EMNEs.

Extant literature acknowledges the importance of home country context in the international venturing strategies of developed country MNEs (lurkov and Benito, 2018; Cuervo-Cazurra and Genc, 2008; Nadkarni and Perez, 2007; Grosse and Trevino, 1996). In this study, we examine how operating in their complex and diverse domestic markets affects the OFDI investments of EMNEs and thus respond to recent calls from scholars to focus attention on home country factors as antecedents of OFDI by EMNEs. Large and diverse emerging economies like India, China, and Brazil offer widespread intra-country linguistic, cultural, institutional and political variations (Dheer et al., 2015; Gaur and Kumar, 2009) that require new products and adaptation of product lines to cater to the specific requirements of a heterogeneous customer base. Also, managing such complex activities in these diverse home markets requires significant resource commitments. Kumar (2009) demonstrated that firms that seek to simultaneously diversify along both, the domestic and international dimensions, will face resource constraints in terms of managerial attention and the abilities of the R\&D, marketing and manufacturing personnel in transferring and absorbing new tacit knowledge from various markets in the short-term. Given these resource constraints, he argues that it would be more prudent for firms to seek growth along a single dimension. It is hence, important to understand whether a diversified portfolio deters or aids overseas investments.

However, there are conditions that could either amplify or attenuate the effect of product diversification on international investments (Mayer et al., 2015). Family firms constitute the majority of publicly listed firms in many emerging economies ( 35 to $66 \%$ of the listed companies in Southeast Asia) (AFBR, 2011), and their strategic choices are different from those of non-family firms due to their unique socioemotional wealth (SEW) considerations (Berrone et al., 2012; Gómez-Mejía et al., 2007). How family firms moderate the relationship between existing product diversification and subsequent international investments of EMNEs is a critical factor. Moreover, there is significant heterogeneity within family firms (Chua et al., 2012), leading to varied outcomes and differential response to the antecedents to OFDI investments. Compared to family-controlled firms (at least $50 \%$ of the shares belong to family members), family-influenced firms (less than $50 \%$ of the shares belong to family members) have different risk preferences because of shared financial risks but have the lesser ability in shaping the family firms' strategies (Ray et al., 2018). Hence, they will have a differential impact on product diversification-international investments relationship. Another important institutionally determined organizational form in the emerging economies is the business group (BG) structure (Gaur and Kumar, 2009; Singh and Gaur, 2009; Khanna and Rivkin, 2001). Due to the strong hold of the family on business, many business groups with varying family ownership, such as the Tata, Birla, or Adani groups, have emerged on the business landscape. We argue that the ability to utilize domestic knowledge in OFDI investments of the business group network will be different from the independent family firms.

We anchor our research in the knowledge-based view of the firm (Low and Ho, 2016; Lu et al., 2014; Habbershon and Williams, 1999; Nahapiet and Ghoshal, 1998; Grant, 1996) and examine the contingent role played by family firms' SEW considerations and the heterogeneity within. We test our prediction 
using a proprietary, longitudinal panel data set of 213 EMNEs from India, of which 175 are family oriented. These EMNEs feature in the S\&P Bombay Stock Exchange (BSE) 500 index. The analysis covers six-years from 2007-08 to 2012-13. We make three specific contributions to the international business and family firm internationalization literature. We partake the debate on the influence of product diversification on international diversification (Batsakis and Mohr, 2017; Mayer et al., 2015; Lu et al., 2014; Kumar, 2009). Our initial results demonstrate that knowledge from product diversification in a diverse and complex domestic market is a distinct advantage for EMNEs that enables them in their decision to invest internationally. Additionally, we show that while knowledge is important and necessary for EMNEs' international expansion, it is not a sufficient condition. We demonstrate that non-family EMNEs that have adopted product diversification strategies are more likely to internationalize through the higher commitment mode of OFDI as compared to comparable family EMNEs. We contend that SEW considerations shape family EMNEs' decisions and hence, these firms are more likely to be skeptical about adopting aggressive growth strategies.

Secondly, we provide evidence on the strategic impact of heterogeneity within family EMNEs. We find that family EMNEs with lower family control are more likely to utilize product diversification knowledge in their OFDI-based internationalization efforts. We reason that greater reliance on SEW as a reference for decision making by firms with greater family control influences the capability to apply acquired domestic knowledge in the OFDI-based internationalization contexts. Thirdly, we demonstrate that product market diversification enables the internationalization of family firms through OFDI to a greater extent when they are affiliated to family business groups. In essence, in this paper, we argue that group structure motivates affiliate firms to expand internationally through OFDI by giving the affiliates access to network-level knowledge resources, thus shaping the risk-bearing capacity of the affiliated firms. Moreover, such network advantages frame the SEW considerations of the family business groups differently from those of independent family firms, and thus, change the reference point for the decision to invest overseas. Our findings add to a more nuanced understanding of the prevailing debate on the differences in internationalization pathways within family EMNEs. Novel perspectives augment our understanding of the internationalization process of EMNEs. We, thereby, respond to the calls of Sharma and Chua (2013) and Wright et al., (2014), encouraging scholars to study the internationalization of family firms from unexplored yet interesting institutional contexts like Asia.

\section{THEORY AND HYPOTHESES}

\section{KNOWLEDGE-BASED VIEW OF THE FIRM AND EMNE'S OFDI EXPANSION}

The 'knowledge-based view of the firm' (KBV) considers knowledge to be the most strategically significant resource for firms to gain sustainable competitive advantage (Grant, 1996; Kogut and Zander, 1992). KBV conceptualizes MNEs as knowledge-sharing systems whose success depends on the MNEs' ability to learn, transfer, and combine knowledge more effectively than their competitors (Kogut and Zander, 1992). While researchers have argued that factors such as economic, political, cultural, and geographic distance have an impact on the FDI flows between countries (Grosse and Trevino, 1996; Ghemawat, 2001), MNEs develop and maintain organizational structures and processes to facilitate knowledge flows within the organization (Ambos and Ambos, 2009). MNEs accumulate experiential knowledge and skills from international operations. MNEs' structures and processes facilitate two-way transfers of this accumulated knowledge and skills between the headquarters and subsidiaries, thereby counterbalancing the liabilities of foreignness and newness in increasingly distant 
international markets (Bartlett and Choshal, 1989; Kogut and Zander, 1993; Barkema, et al., 1996). Although MNEs gain knowledge from a multitude of sources, including subsidiaries and competitors, their home markets remain an important source of knowledge.

Home markets of MNEs have an influence on the international investments of MNEs. In the context of developed country MNEs, Grosse and Trevino (1996) establish the impact of several macroeconomic factors such as size and relative prosperity of the home market, pre-existing trade treaties, cultural and geographic similarity, and political risk on the extent of FDI flows between the home and the host countries. lurkov and Benito (2018) suggest that embeddedness in home country networks leads to the development of strong location-bound firm-specific advantages, thereby reducing the international investments of MNEs. Nadkarni and Perez (2007) argue that the knowledge and learning gained in domestic markets influence the international commitments of firms from developed countries.

In the context of emerging economies, factors like the competition from local and foreign players in the home industry and shortages of strategic resources such as technology and talent may motivate domestic firms to venture abroad (Gaur et al., 2018; Luo and Tung, 2018; 2007). Luo and Tung, (2007, 2018) further argue that EMNEs use international expansion as a springboard to acquire the strategic resources they need to compete in their home markets. In other words, EMNEs invest internationally to seek new knowledge and technology to overcome the weaknesses in their R\&D and knowledge base (Baskaran et al., 2017). Deng (2013) throws further light on the significance of the state in encouraging OFDI and the growth of EMNEs through policy support and ownership of enterprises. Cuervo-Cazurra and Genc (2008) posit that knowledge gained from navigating the institutional voids in their home markets becomes an advantage for EMNEs when competing with developed country MNEs in the least developed countries. Meyer and Grosse (2018) contend that home market conditions in emerging economies enable frugal innovations that help local entrepreneurs compete with developed country MNEs through locally produced "good enough" products, which are subsequently extended to overseas markets. Paul and Benito (2018) categorize home market conditions that influence international investments of EMNEs into push and pull factors - the pull factors being resources that are available abroad to fuel domestic growth, and the push factors being institutional voids which increase transaction costs of domestic operations and positive factors such as policies to facilitate OFDI and institutions that regulate OFDI. Clearly, the effect of the home market environment is complex. It hence becomes important to understand how MNEs, and especially those from emerging markets, leverage home market conditions for their international expansion.

Given the central role of knowledge acquisition, assimilation, and dissemination in explaining firm internationalization, it is quite surprising that precious little is known about the role of knowledge related activities of EMNEs in enabling them to leapfrog directly from exports to OFDI (Gaur et al., 2014). A case in point is India, with its inter-regional disparity in economic and institutional development and different levels of purchasing power. Domestic product diversification may help EMNEs from India develop the requisite expertise and knowledge by operating in a complex and diverse home market.

Product diversification in complex domestic markets encourages EMNEs' international expansion moves by developing EMNEs' coordination skills, knowledge transfer mechanisms, and vicarious learning processes. Product diversification exposes EMNEs to different competitive strategies of domestic and international competitors and enables vicarious learning (Dau, 2012). Customer feedback to these competitive strategies reinforces the vicarious learning of EMNEs (Nadkarni et al., 2011; Nadkarni and Perez, 2007). India is well known for its diversity in culture, religion, ethnicity, language, and food habits. Indian EMNEs undertaking extensive product diversification develop the 
above-mentioned advantages which help them expand overseas as previous strategic decisions generate "internal momentum" impacting future strategic behavior (Child and Rodrigues, 2005; Liu and Buck, 2009). Such knowledge enables EMNEs to develop organizational capabilities about gaining legitimacy and overcoming the liabilities of 'foreignness'.

Bharti Airtel illustrates the role of product diversification in enabling OFDI of EMNEs. Bharti Airtel is a large family-owned business group and was one of the early entrants to the telecom sector in India. Post the liberalization of the Indian economy in 1991, it acquired its first license to operate in 1992 and started providing telephony services by 1995. By 2002, Bharti Airtel was present in different sectors of the telecom business. In the period 2007-2010, Bharti Airtel launched telecom services internationally in Sri Lanka and Bangladesh and entered Africa after buying Zain Group's Africa operations. It expanded into the retail sector in 2007 through an international joint venture and launched its directto-home (DTH) television service in 2008 (Bharti Airtel, 2010). Bharti Airtel developed its expertise in low-cost operations through outsourcing and technology adoption (Giesen et al., 2007). The company innovated novel business models for diverse products in India and then utilized this expertise to enter different international markets.

Knowledge developed in domestic markets is an important resource for international expansion, but, there are other factors at play. In this paper, we examine the moderating role of another significant institutional factor, the family owners' willingness to extend capabilities in investing abroad.

\section{PRODUCT DIVERSIFICATION COST-BENEFIT ANALYSIS AND INTERNATIONAL EXPANSION OF EMNES}

Domestic markets are an important source of experimentation and learning for international expansion strategies by EMNEs. We argue that product diversification enables firms to accumulate knowledge for international expansion (Chandler, 1990) in the following multiple ways. Firstly, it helps develop capabilities that can integrate the knowledge derived from new customers, suppliers, and competitors with its existing knowledge base (Tang et al., 2019). Market intelligence from diverse markets produces a more nuanced analysis of trends, customer needs, and competitor analysis. When such assimilated knowledge is synthesized and shared across the organization, it translates into superior customer value generation.

When EMNEs expand in a foreign market similar to their own, their domestic operating experience generates invaluable market insights and helps combat the 'liabilities of outsidership'. If the firm springboards to dissimilar foreign markets (Luo and Tung, 2007), these capabilities are still relevant and useful in identifying new customer niches, channel partners, suppliers, and competitors (Kumar et al., 2011). Moreover, in order to operate in multiple product markets, firms accumulate generic experience that develops their absorptive capacity (Cohen and Levinthal, 1990) which, further augments the capabilities developed as a result of its multi-market orientation.

Secondly, as opposed to single product firms, managing a successful entry into new product segments with varying customer demands enables EMNE managers to gain proficiency in handling larger responsibilities (Hitt et al., 1997). Lastly, the exposure gained through multi-market competitions help EMNEs to become efficient through increased productivity and innovation, acquire managerial knowledge (Child and Rodrigues, 2005) and develop competencies needed for undertaking OFDI. Due to large scale privatization and deregulation of domestic economies, MNEs of developed countries have begun operations in emerging economies. These firms are generally large with extensive ownership-specific resources and have patient financial slack to survive losses during the gestation period. By competing with the developed country MNEs, EMNEs start improving product 
quality to adhere to international standards by acquiring technological knowledge and managerial skills through investments and spillovers. They also have to configure their strategies to compete with developed country MNEs based on cost advantages or superior customer knowledge. These capabilities, drawn from extensive domestic operations in a competitive market environment are therefore, fungible for international investments of such EMNEs.

Diversification along the dimensions of product and international markets, while, improving the extent of international investments by EMNEs, is also resource-intensive, leading certain scholars to argue that the resultant trade-offs could result in overstretching, which, may result in suboptimal investment decisions (Kumar et al., 2012; Kumar, 2009). However, the resource constraints on firms' activities are short-term in nature, and firms with greater prior experience of diversification develop mechanisms and processes that allow them to overcome the limitations of short-term constraints (Mayer et al., 2015). Moreover, EMNEs are adept at managing resource constraints to compete with developed country MNEs in their domestic markets through frugal innovations (Meyer and Grosse, 2018). EMNEs leverage these capabilities to manage the short-term resource constraints. We hence hypothesize:

\section{Hypothesis 1: Greater the product diversification of EMNEs, higher the OFDI investments.}

\section{THE MODERATING ROLE OF FAMILIAL CONNECTION}

There is general agreement in the academic literature that management practices of family firms are significantly different from those of non-family firms due to the interconnectedness of the family and the business systems in the long run (Gómez-Mejía, et al., 2011; Berrone et al., 2012). This view has been supported by a large body of empirical evidence on some of the smallest and largest, youngest and oldest enterprises, across many countries (Fernández-Aráoz et al., 2015; Zellweger et al., 2012; GómezMejía et al., 2001).

Behavioral agency theorists suggest that family owners are more risk-averse than their non-family counterparts due to the fact that a large proportion of family wealth is invested in the business (Basu et al., 2009; McConaughy et al., 2001). Extending that logic, Gómez-Mejía et al. (2007), developed a general 'SEW model' that complements the behavioral agency model to explain decision-making in family firms. According to this perspective, family owners consider their endowment of SEW, namely 'non-financial aspects of the firm that meet the family's affective needs, such as identity, ability to exercise family influence, and perpetuation of the family dynasty' (Gómez-Mejía et al., 2007, p. 106) worth protecting for emotional reasons (Berrone et al., 2012). In other words, the identity and social status of the family members are closely tied to the business and the preservation of the family's SEW 'represents a key goal in and of itself' (Gómez-Mejía et al., 2007; 2011).

For family firms, risk aversion to socio-emotional endowment takes priority over risk aversion to financial losses, or in other words, the SEW maximization approach becomes the 'real reference point' for decision making (Berrone et al., 2010; Gómez-Mejía et al., 2010; Gómez-Mejía et al., 2007; Zellweger et al., 2012). The fear of losing control and jeopardizing family reputation built up over generations and the financial and social wellbeing of future generations (James, 1999; Schulze et al., 2002) hinder family firms from pursuing risky strategic activities.

Such aversion to risk deters the willingness of family firms to extend their knowledge and capabilities developed in the domestic context to international business. Family firms in emerging economies rely on their social capital to access and screen new business opportunities (Carney, 2005). They are able to leverage institutional voids and exploit opportunities through their relational 
capabilities (Hernández et al., 2018). While operating in multiple product markets, they are able to access market intelligence and synthesize it with existing information through their strong relationships with distributors, suppliers, channel partners and customers developed and nurtured over the long term (De Massis et al., 2013).

However, in order to develop complex organizational structures, processes, and routines, family firms have to formalize many of their relationships, as well as utilize the services of managers, experts, and specialists who can develop these routines, processes, and structures. Effective managerial strength is required for all crucial aspects of the business (Kumar, 2009), but the family may lack the necessary expertise to manage from within the family, the existing and new complex networks of events across geographies (Claver et al., 2009). This issue is exacerbated in diversified firms as in this case, the family would need managers not just for its existing business units, but also for the new ventures. Hence, they need to hire external managers and extend their collaborations with experts and consultants from outside the family (Pukall and Calabrò, 2014), which would result in the weakening of family control and independence, an important element of SEW (Arregle et al., 2012; Zellweger et al., 2012).

Such reluctance to cede authority and control to outsiders, imposes operational constraints on family owners in simultaneously managing a diversified product portfolio and international investments. A resultant divestment may hurt the family's credibility. Collating these arguments, we believe that the average family-owned EMNE that has undertaken substantial product diversification will be unable to exploit its knowledge to expand internationally and hence, more likely to forgo opportunities to invest overseas as compared to non-family EMNEs. Therefore, we hypothesize,

Hypothesis 2: Familial characteristics negatively moderate the relationship between product diversification and OFDI investments by EMNEs.

\section{THE MODERATING ROLE OF FAMILY OWNERSHIP CONTROL}

While research has established the relevance of family business as a focus of academic interest and has highlighted the differences between family and non-family firms, it does not provide sufficient explanation for the performance variance and diversity in strategic choices within family firms. Our study extends previous research on family firms by focusing on differences among family-controlled firms and family-influenced firms to tease out how unilateral family control may impact the domestic product diversification - OFDI based internationalization relationship.

The extent of family ownership is a critical component in retaining family hegemony over the business (Le Breton-Miller et al., 2011; Chrisman et al., 2005). When family members own a relatively small share, they have limited SEW invested and a weaker desire to preserve SEW. Failure is unlikely to damage their economic status and SEW. In contrast, the higher the family ownership, greater is their financial wealth investment and this gives the family the discretionary power to decide the firm's strategic development - 'in such firms, the family is a dominant influence, thus, making strategic choices based on family-identity attributes, such as values and goals, with their associated advantages and disadvantages, is more legitimate and common' (Arregle et al., 2012; Zellweger et al., 2013). As higher international investments expose family firms to greater environmental and organizational uncertainties and a higher probability of failure, highly family-controlled EMNEs are reluctant to pursue high-risk strategies.

In contrast, family EMNEs with low family ownership have already divested a certain degree of control and are less reluctant to accept external resources from other investors. Non-family individual 
and institutional shareholders have access to networks distinct from the familial owners in terms of finance and information. Moreover, non-family owners also provide countervailing views in strategic decisions that can mitigate the consequences of family owners' risk aversion or group think (Arregle et al., 2012). The resources provided by non-family owners are of critical importance as they provide optimization without increasing the operational risks. These resources help in developing organizational structures, processes, and routines that can organize and integrate complex information from diverse sources and leverage them in varied contexts. Further, non-family shareholders also transform the family-influenced firms from simple mindsets to complex domestic mindsets through their own experiential learning and information networks (Nadkarni and Perez, 2007). Such a change in mindset helps overcome the psychic distance associated with international expansion.

Hence, due to a narrower base of knowledge, reluctance to cede control, lesser access to the talent required to manage complex operations, the higher risks to business and SEW, as well as the higher volatility in cash flows, highly diversified family-controlled EMNEs are less likely to exploit the knowledge developed from operations in domestic product markets to pursue high risk, high commitment OFDI based internationalization, as compared to family-influenced EMNEs. Therefore, we argue that:

Hypothesis 3: Family ownership negatively moderates the relationship between product diversification and OFDI investments by family-EMNEs.

\section{THE MODERATING ROLE OF FAMILY BUSINESS GROUP AFFILIATION}

Affiliation to family business groups (FBGs) is a key feature of many firms in emerging economies like India. Defined as 'a business entity that consists of diversified affiliate firms that are associated through multiple links, including pyramidal ownership structure, close market ties (such as inter-firm transactions), and family relations through which the firms coordinate to achieve shared objectives' (Chung, 2013: 871; La Porta et al., 1999), public shareholders are brought in to provide capital but the control rests firmly with the family in the family business groups (Morck and Yeung, 2003).

As with family firms, familial considerations and SEW as the reference for decision-making continue to hold for family business groups (Gu et al., 2019). The trade-offs that family firms unaffiliated to family business groups have to consider for strategic choices are significantly different from those of the family business group affiliates in terms of resources, knowledge, and expertise.

The network structure of family business groups provides affiliates with the advantages of preferential access to inputs and outputs of the production processes, internal capital markets, and internal labor markets (Khanna and Palepu, 2000). Affiliates can use these resources to support the activities of their foreign affiliates (Singh and Gaur, 2009; Zattoni et al., 2009; Masulis et al., 2011). Further, family business groups have additional affect-related considerations, such as nurturing the next generation and succession planning that impact their strategic decisions such as entering new markets and overcome the costs of product diversification. The entry of family business groups into new markets gives family members a larger pie that the leaders of the family business group can carve out to grant autonomy and reduce conflicts in the succession process. Moreover, it provides opportunities for the next generation to learn and expand their career prospects (Gu et al., 2019).

The diversification of family business groups provides certain key non-market benefits to the affiliates that can aid in the international expansion process. For instance, higher the diversification of the family business group, more significant is its clout in the domestic market by dint of its impact on 
the economy. This clout provides the family with privileged access to information, control over valuable resources, and vital political contacts (Fisman, 2001). Diversified family business groups can use this access to privileged information and political clout to navigate the institutional voids, as well as obtain favorable treatment for setting up operations abroad (Borda et al., 2017; Deng, 2013). The family business groups also have a strong sense of group identity (Granovetter, 2005; Guillén, 2002), which promotes the sharing of best practices and suitable strategies to be pursued in foreign markets. Thus, the absorptive capacity of the group, rather than a single standalone firm, aids in the internationalization process.

Therefore, we argue that affiliated firms enjoy certain resource-level advantages that independent family firms do not, albeit both have similar loss aversion. Family business group affiliates can learn from their operations in different product markets and, where necessary, supplement that knowledge from other affiliated family firms. Such knowledge sharing across the family business group, will strengthen the domestic complexity mindset of the focal firm, unlike the independent family firms that would have to rely on external resources. Moreover, succession related issues will induce the group to adopt extensive growth strategies. Overall, the ultimate objective of family business group affiliated firms is to preserve SEW. Compared to independent family firms, family business group affiliates' access to superior network-level resources provides them with an impetus to leverage the knowledge gained from product diversification to expand internationally through OFDI. Hence, we hypothesize:

Hypothesis 4: Affiliation to a family business group positively moderates the relationship between product diversification and OFDI investments by family EMNEs.

\section{METHODOLOGY}

\section{DATA}

After China, India, has been home to the largest number of EMNEs (BCG, 2013). Indian EMNEs constitute an appropriate sample for our research for two important reasons. Firstly, India has undergone significant liberalization measures since the early nineties, which eased and facilitated significant investment outflows to foreign markets. Recent research on the internationalization of Indian EMNEs suggests a fundamental shift in the internationalization trajectories with more emphasis on OFDI-based internationalization as compared to pure exports, both in developed as well as developing economies (Gaur et al., 2014). The study of the antecedents of EMNEs' OFDI based internationalization has become an area of keen scholarly interest (Chittoor et al., 2015; Gubbi et al., 2015). Secondly, India has a long history of family and community-based firms (Howorth et al., 2006). The significant overlap between the family and business systems in India often shapes their strategic choices. Moreover, India's socio-economic and cultural diversity is reflected in the heterogeneity of family EMNEs and their internationalization efforts. This heterogeneity, along with the attendant variations in their strategic choices, creates a quasi-natural experimental setting to examine our research questions of interest.

We chose the five hundred companies that feature in the Bombay Stock Exchange (BSE, the oldest in India) 500 index, comparable to global S\&P 500, as our initial sample set. The index represents nearly $93 \%$ of the total market capitalization of firms listed in the BSE. Moreover, as some of the largest firms in developing countries account for the OFDI investments from these countries (Dau, 2012), our selection of S\&P BSE 500 firms is appropriate to test our theoretical propositions related to the OFDI based internationalization. 
We found a total of 249 MNEs, both family-owned and independent ones, from 2007 to 2013. As we are concerned with the international expansion of Indian firms only, we eliminated 10 Indian subsidiaries of foreign MNEs from that list. We excluded 13 financial services industry firms to avoid complications from different applicable accounting principles and regulations for OFDI in this industry. Furthermore, we removed ten central government owned public sector enterprises. Also, three companies did not disclose complete information on their foreign operations even in their annual reports; hence these firms were dropped from the sample. Our research examined a final sample of 213 MNEs, of which 175 were family-owned, and the rest were independent firms.

We conducted a two-step data collection process to collect the information of our interest in a comprehensive manner. Data corresponding to our main dependent variables like OFDI intensity and other firm-level financial information like family shareholdings, family business group affiliation status, etc., were taken directly from Prowess, a database used extensively in extant studies of Indian firms (Gadepalli and Mondal, 2018; Chittoor et al., 2015; Gubbi et al., 2015; Khanna and Palepu, 2000). In the second step of data collection, to check the robustness of our results, we sifted through the annual financial reports of all companies in the sample for the period 2007-2013 to collect data about their foreign subsidiaries. 
Table 1. Sample Distribution

\begin{tabular}{|c|c|c|}
\hline 2-Digit NIC & $\begin{array}{l}\text { Percentage of } \\
\text { Observations }\end{array}$ & Industry \\
\hline 10 & 4.62 & Manufacture of food products \\
\hline 11 & 0.84 & Manufacture of beverages \\
\hline 13 & 1.40 & Manufacture of textiles \\
\hline 16 & 0.84 & $\begin{array}{l}\text { Manufacture of wood and products of wood and } \\
\text { cork }\end{array}$ \\
\hline 17 & 0.84 & Manufacture of paper and paper products \\
\hline 19 & 1.82 & $\begin{array}{l}\text { Manufacture of coke and refined petroleum } \\
\text { products }\end{array}$ \\
\hline 20 & 9.93 & Manufacture of chemicals and chemical products \\
\hline 21 & 12.31 & $\begin{array}{l}\text { Manufacture of pharmaceuticals, chemical \& } \\
\text { botanical products }\end{array}$ \\
\hline 22 & 4.90 & Manufacture of rubber and plastics products \\
\hline 23 & 4.48 & $\begin{array}{l}\text { Manufacture of other non-metallic mineral } \\
\text { products }\end{array}$ \\
\hline 24 & 6.85 & Manufacture of basic metals \\
\hline 25 & 1.26 & Manufacture of fabricated metal products \\
\hline 26 & 0.84 & Manufacture of fabricated metal products \\
\hline 27 & 1.26 & Manufacture of electrical equipment \\
\hline 28 & 4.90 & Manufacture of machinery and equipment n.e.c \\
\hline 29 & 0.84 & $\begin{array}{l}\text { Manufacture of motor vehicles, trailers and semi- } \\
\text { trailers }\end{array}$ \\
\hline 30 & 5.45 & Manufacture of other transport equipment \\
\hline 32 & 0.98 & Other manufacturing activities \\
\hline 34 & 2.80 & $\begin{array}{l}\text { Repair and installation of machinery and } \\
\text { equipment }\end{array}$ \\
\hline 35 & 1.96 & Electricity, gas, steam and air conditioning supply \\
\hline 41 & 0.14 & Construction of buildings \\
\hline 42 & 3.92 & Civil engineering \\
\hline 46 & 2.94 & $\begin{array}{l}\text { Wholesale trade, except of motor vehicles and } \\
\text { motorcycles }\end{array}$ \\
\hline 47 & 0.56 & $\begin{array}{l}\text { Retail trade, except of motor vehicles and } \\
\text { motorcycles }\end{array}$ \\
\hline 50 & 0.84 & Water transport \\
\hline 52 & 0.14 & $\begin{array}{l}\text { Warehousing and support activities for } \\
\text { transportation }\end{array}$ \\
\hline 55 & 2.52 & Accommodation \\
\hline 61 & 2.94 & Telecommunications \\
\hline 62 & 10.49 & $\begin{array}{l}\text { Computer programming, consultancy and related } \\
\text { activities }\end{array}$ \\
\hline 63 & 1.40 & Information service activities \\
\hline 64 & 1.26 & Financial service activities \\
\hline 68 & 1.12 & Real estate activities \\
\hline 70 & 0.84 & $\begin{array}{l}\text { Activities of head offices; management } \\
\text { consultancy }\end{array}$ \\
\hline 71 & 0.14 & Architecture and engineering activities \\
\hline 78 & 0.56 & Employment activities \\
\hline 86 & 1.12 & Human health activities \\
\hline
\end{tabular}


Table 1 provides an overview of the sample in terms of key industries and their 2-digit NIC-level (similar to SIC) industry codes. In our sample, 12 percent of the observations come from the manufacturers of pharmaceutical products, near about 11 percent from the software services, almost 10 percent from the producers of chemical and chemical products and 7 percent from the manufacturers of basic metals and the rest from other types of manufacturing and services. Almost 26 percent of our observations are from the services sector and the remaining 74 percent from the manufacturing sector.

\section{DEPENDENT VARIABLE}

Our dependent variable is international investments of Indian EMNEs. We evaluate OFDI intensity as the ratio of foreign investments to total assets of the firm (Bhaumik et al., 2010; Chari, 2013). By taking foreign investments as the numerator, this measure automatically captures a more involved or higher 'commitment' mode of internationalization as compared to exports (Johanson and Vahlne, 1977: 27). We used alternate measures of the dependent variable to check the robustness of our analyses. We compared our results with another measure of OFDI internationalization with foreign investments as a percentage of the total capital that firms employ in their domestic and international projects. Also, although OFDI intensity captures the extent of international investments, this does not differentiate between firms with investments in joint ventures and alliances with firms that have multiple wholly owned operations abroad. As a result, OFDI intensity often fails to illustrate the extent and array of a firm's practical operations abroad (Dau, 2012). Therefore, we used a more precise measure - namely, the number of foreign subsidiaries of the firm-to measure the scale of a firm's multinational practical operations, as is often used by IB scholars (Lu and Beamish, 2001; Makino et al., 2004; Dau, 2012). In both cases, we observed no qualitative difference in our results, suggesting the findings are quite robust to alternate specifications.

\section{INDEPENDENT AND MODERATING VARIABLES}

\section{PRODUCT DIVERSIFICATION}

We rely on the product-mix information collated by Prowess database to track a firm's product diversification over time. We use the number of products offering in any particular NIC industry (equivalent to SIC in the Indian context) as the weights in Herfindahl index computation (Zahavi and Lavie, 2013). We calculate Herfindahl diversity measure using the formula (Montgomery, 1982):

$$
\text { Product Diversification }_{i, t}=1-\frac{\Sigma_{j} M_{i j t}^{2}}{\left(\Sigma_{j} M_{i j t}\right)^{2}}
$$

Where, $M_{i j t}$ is the proportion of active products of firm $i$ in market segment $j$ in year $t$. This expression is essentially the number of products that the firm has in a particular market segment, divided by the total number of products it has in all market segments in a given year (Nath et al., 2011). The main advantage of this measure is its ability to capture the diversity of market segments by considering the proportion of products introduced in each segment. Extant literature has used such measures of diversity in the context of many business group studies in emerging economies (e.g. Khanna and Palepu, 2000; Kumar et al., 2012), thus validating its reliability. 


\section{FAMILY FIRM}

Based on the principles conceptualized by prior research studies (Ray et al., 2018; Singla et al., 2014), we constructed the family firm (FF) variable through a dummy variable that took the value of one as per the following criteria: the founding family has a minimum stake of 20 percent in the firm and either of the following two criteria are met: (i) a member of the family is either on the board; and/or (ii) the Chairperson of the Board, Managing Director or the CEO of the firm.

\section{FAMILY-CONTROLLED FIRM}

As family firms are heterogeneous in terms of family's involvement in the firm, Sirmon et al., (2008) suggest that it is useful to differentiate between family-influenced and family-controlled firms. We operationalize family-controlled firms through a dummy variable that takes the value of one if the family unilaterally controls the firm through majority ownership (i.e., at least 50\% of the shares) and has managerial and/or board presence (Sirmon et al., 2008; Westhead and Howorth, 2007); else zero. Hence, our study compares not only family and non-family firms but also differences within family firms.

\section{FAMILY BUSINESS GROUP AFFILIATES}

To understand the effects of family business group affiliation, the family firms were dummy coded as belonging to family business group $(1$, else 0$)$ if it belonged to a business group as classified by Prowess database.

\section{CONTROL VARIABLES}

We include numerous control variables to account for confounding effects. The extant literature has argued that larger firms have greater financial and non-financial resources that are conducive to internationalization and vice-versa (Chen et al., 2016; Tihanyi et al., 2000). We use firm size, measured as the natural logarithm of total sales, to control for size effects on the firm's OFDI efforts. Since older firms have a greater ability to collect information about international operations and build the infrastructure for internationalization (and vice versa), firm age is controlled and measured as the log of the years a firm has been in existence (Zahra, 2003). We control for export intensity, computed as the ratio of exports to total sales, to control for its knowledge-based influence on OFDI investments; we control for current ratio and debt to equity ratio because available financial slack has an impact on internationalization (Tihanyi et al., 2003). Since greater investments in R\&D and marketing activities are associated with higher levels of international expansion (Chittoor et al., 2009; Herrmann and Datta, 2005), we control for them in our analysis. We measure $R \& D$ intensity by computing its annual expenses as a percentage of sales and marketing intensity by computing total annual marketing expenses as a percentage of sales. We also control for the level of pro-market reforms implemented in India because liberalization and economic reforms influence domestic firms' internationalization trajectories (Chari, 2013; Dau, 2012). We measured pro-market reforms with the International Monetary Fund's structural reforms index (Sahay and Goyal 2006). This index ranges from 0 to 100, with higher values representing a higher level of pro-market reforms. Dummy variables to control the potential effects of macroeconomic conditions and industry dummies (at two-digit NIC level) to control industry effects were also used. Finally, there is extensive literature arguing that firm's prior profitability may 
influence its international expansion decisions, we hence, controlled for this by measuring prior profitability as the percentage of earnings before depreciation, interest, and taxes to total assets (Gómez-Mejía et al., 2010; Ray et al., 2018; Kumar et al., 2020).

\section{MODEL SPECIFICATION AND RESULTS}

We test our hypotheses using generalized least square (GLS) models for panel data, with correction for heteroscedasticity and autocorrelation. This model is adequate for panel data, as GLS produces residuals that estimate the unit-specific serial correction of the errors associated with panel data and transforms the model into one with serially independent errors (Beck and Katz, 1995). We can also examine the time series component of the analysis and maximize the degrees of freedom (Lee et al., 2008). In all our models, the dependent variables (from 2008 to 2013) are regressed against the lagged independent and control variables (from 2007 to 2012) to ensure that the direction of causality is from product diversification to OFDI investments and not the reverse (Lee and Park, 2008). Furthermore, we check for various assumptions of data and analysis including normality of residuals, heteroscedasticity and collinearity diagnostics. All the VIF values are less than 2.5, indicating that multicollinearity is not an issue. Table 2 presents the descriptive statistics of the variables used to test the difference between family and non-family firms, and Table 3 depicts the descriptive statistics of the sample used to tease out the effect of heterogeneity of family firms.

The average firm in our sample has been operational for thirty years, with an average return on assets of over ten percent, spends about three percent of its sales on marketing and one percent on $R \& D$, and earned twenty-nine percent of its sales through exports. This firm has ten percent of its investments overseas. 
Table 2. Means, Standard Deviations, and Correlations: Full Sample of 975 Observations

\begin{tabular}{|c|c|c|c|c|c|c|c|c|c|c|c|c|c|c|}
\hline & Mean & S.D. & 1 & 2 & 3 & 4 & 5 & 6 & 7 & 8 & 9 & 10 & 11 & 12 \\
\hline $\begin{array}{l}\text { OFDI Intensity } \\
\text { (\%) }\end{array}$ & 10.2664 & 14.3942 & 1.000 & & & & & & & & & & & \\
\hline $\begin{array}{c}\text { Product } \\
\text { Diversification }\end{array}$ & 0.7107 & 0.4053 & $\begin{array}{l}0.1076 \\
* * *\end{array}$ & 1.000 & & & & & & & & & & \\
\hline $\begin{array}{l}\text { Family Firms } \\
\text { (yes=1, else=0) }\end{array}$ & 0.7933 & 0.3898 & $\begin{array}{l}-0.0644 \\
* *\end{array}$ & $\begin{array}{l}0.0690 \\
* *\end{array}$ & 1.000 & & & & & & & & & \\
\hline $\begin{array}{c}\text { Prior } \\
\text { Profitability (\%) }\end{array}$ & 10.6770 & 9.043 & $\begin{array}{l}-0.0566 \\
*\end{array}$ & -0.0161 & $\begin{array}{l}-0.110 \\
* * *\end{array}$ & 1.000 & & & & & & & & \\
\hline Current Ratio & 1.2942 & 0.9061 & 0.0077 & $\begin{array}{l}-0.1462 \\
* * * *\end{array}$ & $\begin{array}{l}-0.0937 \\
* *\end{array}$ & $\begin{array}{l}0.2151 \\
* * *\end{array}$ & 1.000 & & & & & & & \\
\hline $\begin{array}{c}\text { Debt/Equity } \\
\text { Ratio }\end{array}$ & 0.7593 & 1.1017 & $\begin{array}{l}-0.0673 \\
* *\end{array}$ & $\begin{array}{l}0.0688 \\
* *\end{array}$ & $\begin{array}{l}0.1156 \\
* * *\end{array}$ & $\begin{array}{l}-0.3649 \\
* * *\end{array}$ & $\begin{array}{l}-0.1424 \\
* * *\end{array}$ & 1.000 & & & & & & \\
\hline $\begin{array}{c}\text { Marketing } \\
\text { Intensity (\%) }\end{array}$ & 2.5345 & 4.4846 & $\begin{array}{l}0.1680 \\
* * *\end{array}$ & $\begin{array}{l}-0.0930 \\
* *\end{array}$ & $\begin{array}{l}0.1638 \\
* * *\end{array}$ & $\begin{array}{l}-0.073 \\
* *\end{array}$ & $\begin{array}{l}0.061 \\
*\end{array}$ & 0.0246 & 1.000 & & & & & \\
\hline $\begin{array}{c}\text { R \& D Intensity } \\
(\%)\end{array}$ & 0.8341 & 1.939 & $\begin{array}{l}0.2025 \\
* * *\end{array}$ & $\begin{array}{l}-0.1598 \\
* * *\end{array}$ & $\begin{array}{l}0.0795 \\
* *\end{array}$ & 0.0332 & $\begin{array}{l}0.123 \\
* * *\end{array}$ & -0.035 & $\begin{array}{l}0.2317 \\
* * *\end{array}$ & 1.000 & & & & \\
\hline Firm $\mathrm{age}^{\mathrm{a}}$ & 3.3928 & 0.6552 & $\begin{array}{l}-0.1344 \\
* * *\end{array}$ & $\begin{array}{l}0.2119 \\
* * *\end{array}$ & $\begin{array}{l}0.0978 \\
* *\end{array}$ & 0.0141 & -0.0483 & 0.0360 & $\begin{array}{l}-0.1476 \\
* * *\end{array}$ & -0.0173 & 1.000 & & & \\
\hline Firm sales ${ }^{b}$ & 9.7827 & 1.5705 & $\begin{array}{l}-0.1467 \\
* * *\end{array}$ & $\begin{array}{l}0.1194 \\
* * *\end{array}$ & -0.0063 & $\begin{array}{l}0.0847 \\
* *\end{array}$ & $\begin{array}{l}-0.1646 \\
* * *\end{array}$ & $\begin{array}{l}0.0656 \\
* *\end{array}$ & $\begin{array}{l}-0.3167 \\
* * *\end{array}$ & $\begin{array}{l}-0.1013 \\
* *\end{array}$ & $\begin{array}{l}0.2364 \\
* * *\end{array}$ & 1.000 & & \\
\hline $\begin{array}{c}\text { Export } \\
\text { Intensity (\%) }\end{array}$ & 28.8272 & 30.1381 & $\begin{array}{l}0.1621 \\
* * *\end{array}$ & $\begin{array}{l}-0.1486 \\
* * *\end{array}$ & $\begin{array}{l}-0.1330 \\
* * *\end{array}$ & $\begin{array}{l}0.1516 \\
* * * *\end{array}$ & $\begin{array}{l}0.2492 \\
* * *\end{array}$ & $\begin{array}{l}-0.093 \\
* *\end{array}$ & -0.0448 & $\begin{array}{l}0.2250 \\
* * *\end{array}$ & $\begin{array}{l}-0.2004 \\
* * *\end{array}$ & $\begin{array}{l}-0.1213 \\
* * *\end{array}$ & 1.000 & \\
\hline $\begin{array}{l}\text { Pro-market } \\
\text { reform }\end{array}$ & 54.2791 & 0.3267 & -0.0209 & -0.0198 & 0.0209 & $\begin{array}{l}-0.0620 \\
*\end{array}$ & 0.0016 & 0.0364 & -0.0311 & 0.0024 & 0.0289 & $\begin{array}{l}0.0813 \\
* *\end{array}$ & $\begin{array}{l}-0.0608 \\
*\end{array}$ & 1.000 \\
\hline
\end{tabular}


Table 3. Means, Standard Deviations, and Correlations: Sub-sample of 793 Family Firms' Observations

\begin{tabular}{|c|c|c|c|c|c|c|c|c|c|c|c|c|c|c|c|}
\hline & Mean & S.D. & 1 & 2 & 3 & 4 & 5 & 6 & 7 & 8 & 9 & 10 & 11 & 12 & 13 \\
\hline $\begin{array}{l}\text { OFDI Intensity } \\
(\%)\end{array}$ & 9.8224 & 14.4360 & 1.000 & & & & & & & & & & & & \\
\hline $\begin{array}{c}\text { Product } \\
\text { Diversification }\end{array}$ & 0.7332 & 0.4006 & $\begin{array}{l}0.0695 \\
* *\end{array}$ & 1.000 & & & & & & & & & & & \\
\hline $\begin{array}{l}\text { Family Firms } \\
\text { (yes=1, else=0) }\end{array}$ & 0.4351 & 0.4961 & $\begin{array}{l}-0.0715 \\
* *\end{array}$ & $\begin{array}{l}-0.1251 \\
* * * *\end{array}$ & 1.000 & & & & & & & & & & \\
\hline $\begin{array}{c}\text { Family Business } \\
\text { Group Affiliates } \\
(1, \text { else } 0)\end{array}$ & 0.8103 & 0.3738 & 0.0554 & -0.0468 & $\begin{array}{l}0.1507 \\
* * *\end{array}$ & 1.000 & & & & & & & & & \\
\hline $\begin{array}{c}\text { Prior } \\
\text { Profitability (\%) }\end{array}$ & 10.2010 & 8.9709 & $\begin{array}{l}-0.0763 \\
* *\end{array}$ & -0.0217 & $\begin{array}{l}0.1386 \\
* * *\end{array}$ & 0.0465 & 1.000 & & & & & & & & \\
\hline Current Ratio & 1.2536 & 0.8851 & 0.0109 & $\begin{array}{l}-0.1541 \\
* * * *\end{array}$ & 0.0371 & -0.0364 & $\begin{array}{l}0.1735 \\
* * * *\end{array}$ & 1.000 & & & & & & & \\
\hline $\begin{array}{l}\text { Debt/Equity } \\
\text { Ratio }\end{array}$ & 0.8202 & 1.1555 & $\begin{array}{l}-0.0614 \\
*\end{array}$ & $\begin{array}{l}0.0628 \\
*\end{array}$ & -0.0213 & -0.0337 & $\begin{array}{l}-0.3352 \\
* * *\end{array}$ & $\begin{array}{l}-0.1232 \\
* * *\end{array}$ & 1.000 & & & & & & \\
\hline $\begin{array}{l}\text { Marketing } \\
\text { Intensity (\%) }\end{array}$ & 2.8864 & 4.8338 & $\begin{array}{l}0.1863 \\
* * * *\end{array}$ & $\begin{array}{l}-0.1226 \\
* * *\end{array}$ & $\begin{array}{l}0.1969 \\
* * *\end{array}$ & $\begin{array}{l}0.0803 \\
* *\end{array}$ & $\begin{array}{l}-0.0601 \\
*\end{array}$ & $\begin{array}{l}0.0966 \\
* *\end{array}$ & 0.0147 & 1.000 & & & & & \\
\hline $\begin{array}{c}\text { R \& D Intensity } \\
\text { (\%) }\end{array}$ & 0.9080 & $2.045^{8}$ & $\begin{array}{l}0.2582 \\
* * *\end{array}$ & $\begin{array}{l}-0.1738 \\
* * *\end{array}$ & 0.0264 & -0.0082 & 0.0493 & $\begin{array}{l}0.1314 \\
* * *\end{array}$ & -0.0426 & $\begin{array}{l}0.2321 \\
* * *\end{array}$ & 1.000 & & & & \\
\hline Firm age $\mathrm{ag}^{\mathrm{a}}$ & 3.4235 & 0.6816 & $\begin{array}{l}-0.1012 \\
* *\end{array}$ & $\begin{array}{l}0.2390 \\
* * *\end{array}$ & $\begin{array}{l}-0.1844 \\
* * *\end{array}$ & $\begin{array}{l}0.1097 \\
* *\end{array}$ & 0.0129 & -0.0176 & 0.0154 & $\begin{array}{l}-0.1718 \\
* * *\end{array}$ & 0.0396 & 1.000 & & & \\
\hline Firm sales & 9.7779 & 1.4950 & $\begin{array}{l}-0.0679 \\
*\end{array}$ & $\begin{array}{l}0.1268 \\
* * *\end{array}$ & $\begin{array}{l}-0.1494 \\
* * *\end{array}$ & $\begin{array}{l}0.2261 \\
* * * *\end{array}$ & $\begin{array}{l}0.1031 \\
* *\end{array}$ & $\begin{array}{l}-0.2010 \\
* * *\end{array}$ & 0.0422 & $\begin{array}{l}-0.3600 \\
* * *\end{array}$ & $\begin{array}{l}-0.1156 \\
* *\end{array}$ & $\begin{array}{l}0.1446 \\
* * *\end{array}$ & 1.000 & & \\
\hline $\begin{array}{l}\text { Export Intensity } \\
\text { (\%) }\end{array}$ & 26.9080 & 27.5901 & $\begin{array}{l}0.1305 \\
* * *\end{array}$ & $\begin{array}{l}-0.1676 \\
* * *\end{array}$ & $\begin{array}{l}-0.1217 \\
* * *\end{array}$ & $\begin{array}{l}-0.1480 \\
* * *\end{array}$ & 0.0736 & $\begin{array}{l}0.2285 \\
* * *\end{array}$ & -0.0308 & -0.0262 & $\begin{array}{l}0.2770 \\
* * *\end{array}$ & $\begin{array}{l}-0.1681 \\
* * *\end{array}$ & $\begin{array}{l}-0.0770 \\
* *\end{array}$ & 1.000 & \\
\hline $\begin{array}{l}\text { Pro-market } \\
\text { reform }\end{array}$ & 54.2824 & 0.3262 & -0.0098 & -0.0191 & 0.0460 & -0.0067 & $\begin{array}{l}-0.0747 \\
* *\end{array}$ & 0.0300 & 0.0329 & -0.0478 & -0.0088 & 0.0220 & $\begin{array}{l}0.0862 \\
* *\end{array}$ & $\begin{array}{l}-0.0685 \\
*\end{array}$ & 1.000 \\
\hline
\end{tabular}

Among our samples, approximately seventy-nine percent of the firms are family owned and from among these family firms, forty-five percent are family-controlled while the rest are family-influenced firms. Also, around eighty percent of them are affiliated to family business groups and the rest are independent. We conducted Wilcoxon signed-rank tests of the difference of medians (Khanna and Palepu, 2000) for the key variables between the sample representing family business group affiliates and independent family firms. We find that the differences in the OFDI intensity, export intensity, size, age, and diversification, between family business group affiliates and independent family firms are significant at $p<0.001$. These results indicate that family business group affiliates' strategic behavior is significantly different from the independent firms, despite the latter's limited representation in our sample. Overall, our sample set shows a good balance in composition in terms of size, age, ownership, exporting behavior, overseas internationalization activities, and industry diversity. The GLS regression results, related to the impact of several explanatory variables on OFDI activities, are provided in Table 4. 
From among the control variables, we find that prior profitability, leverage, firm age, and firm size have a negative relationship with OFDI. The negative relationship between prior profitability and OFDI could be because profitable firms do not face the same threats that motivate firms to increase their international investments. Moreover, firms require significant investments in their domestic operations to pursue the path of profitability and to counter competition.

Firms might also be resource-constrained in making investments in domestic and international investments simultaneously, which manifests in the negative relationship between prior profitability and OFDI. Firms with high leverage are likely to see a greater outflow of interest charges, leaving them with limited funds for investments in international operations. Older and larger firms might not have the flexibility to streamline their operations to factor in additional complexities of product and international diversification. The rigidity of their processes due to which firms cannot transfer tacit knowledge as required, is likely to result in the negative relationship between age and size and OFDI. Moreover, these results conform to those in the extant literature on foreign investments by EMNEs, which suggest that smaller and younger firms are more entrepreneurial and have less organizational inertia, and are hence, more likely to undertake OFDI (Kumar et al., 2020; Ray et al., 2018; Madhok and Keyhani, 2012). We also observe that R\&D intensity has a positive and significant relationship with OFDI, suggesting that firms that invest in $R \& D$ develop significant competitive advantages. Such firms can leverage their experience in new geographies and increase their OFDI investments. 
Table 4: Regression Analysis

\begin{tabular}{|c|c|c|c|c|c|c|c|}
\hline & $\begin{array}{c}\text { Model } 1 \\
\text { OFDI } \\
\text { Intensity }\end{array}$ & $\begin{array}{l}\text { Model } 2 \\
\text { OFDI } \\
\text { Intensity }\end{array}$ & $\begin{array}{l}\text { Model } 3 \\
\text { OFDI } \\
\text { Intensity }\end{array}$ & $\begin{array}{l}\text { Model } 4 \\
\text { OFDI } \\
\text { Intensity } \\
\end{array}$ & $\begin{array}{l}\text { Model } 5 \\
\text { OFDI } \\
\text { Intensity }\end{array}$ & $\begin{array}{l}\text { Model } 6 \\
\text { OFDI } \\
\text { Intensity }\end{array}$ & $\begin{array}{l}\text { Model } 7 \\
\text { OFDI } \\
\text { Intensity }\end{array}$ \\
\hline Product Diversification & $\begin{array}{l}1.4284 \\
* * *\end{array}$ & $\begin{array}{l}1.6623 \\
* * *\end{array}$ & $\begin{array}{l}1.6860 \\
* * *\end{array}$ & $\begin{array}{l}1.1227 \\
* * *\end{array}$ & $\begin{array}{l}1.0872 \\
* * *\end{array}$ & $\begin{array}{l}1.1036 \\
* * *\end{array}$ & $\begin{array}{l}1.1503 \\
* * *\end{array}$ \\
\hline Family Firms & & $\begin{array}{l}-0.8588 \\
* * *\end{array}$ & $\begin{array}{l}-0.7691 \\
* * *\end{array}$ & & & & \\
\hline $\begin{array}{l}\text { Product Diversification * } \\
\text { Family Firms }\end{array}$ & & & $\begin{array}{l}-1.2113 \\
* * *\end{array}$ & & & & \\
\hline $\begin{array}{l}\text { Family-controlled firms } \\
\qquad(1, \text { else } 0)\end{array}$ & & & & $\begin{array}{l}-0.5519 \\
* * *\end{array}$ & $\begin{array}{l}-0.6591 \\
* * *\end{array}$ & & \\
\hline $\begin{array}{l}\text { Product Diversification * } \\
\text { Family-controlled firms }\end{array}$ & & & & & $\begin{array}{l}-0.1959 \\
*\end{array}$ & & \\
\hline $\begin{array}{l}\text { Family Business Group } \\
\text { Affiliates } \\
(\mathbf{1}, \text { else } 0)\end{array}$ & & & & & & $\begin{array}{l}0.7224 \\
* * *\end{array}$ & $\begin{array}{l}0.8140 \\
* * *\end{array}$ \\
\hline $\begin{array}{l}\text { Product Diversification * } \\
\text { Family Business Group } \\
\text { Affiliates }\end{array}$ & & & & & & & $\begin{array}{l}0.2633 \\
* *\end{array}$ \\
\hline Prior Profitability (\%) & $\begin{array}{l}-0.0845 \\
* * *\end{array}$ & $\begin{array}{l}-0.0920 \\
* * *\end{array}$ & $\begin{array}{l}-0.0937 \\
* * *\end{array}$ & $\begin{array}{l}-0.1151 \\
* * *\end{array}$ & $\begin{array}{l}-0.1196 \\
* * *\end{array}$ & $\begin{array}{l}-0.1262 \\
* * *\end{array}$ & $\begin{array}{l}-0.1230 \\
* * *\end{array}$ \\
\hline Current Ratio & -0.0235 & -0.0797 & -0.0572 & 0.1721 & 0.1207 & 0.1679 & $\begin{array}{l}0.1767 \\
* *\end{array}$ \\
\hline Debt/Equity Ratio & $\begin{array}{l}-0.4555 \\
* * *\end{array}$ & $\begin{array}{l}-0.4995 \\
* * *\end{array}$ & $\begin{array}{l}-0.4335 \\
* *\end{array}$ & $\begin{array}{l}-0.5605 \\
* * *\end{array}$ & $\begin{array}{l}-0.6067 \\
* * *\end{array}$ & $\begin{array}{l}-0.5646 \\
* * *\end{array}$ & $\begin{array}{l}-0.5544 \\
* *\end{array}$ \\
\hline Marketing Intensity (\%) & $\begin{array}{l}0.1183 \\
* *\end{array}$ & $\begin{array}{l}0.1582 \\
* * *\end{array}$ & $\begin{array}{l}0.0872 \\
*\end{array}$ & $\begin{array}{l}0.1071 \\
* *\end{array}$ & $\begin{array}{l}0.0981 \\
* *\end{array}$ & 0.0086 & 0.0117 \\
\hline R\&D Intensity (\%) & $\begin{array}{l}1.7727 \\
* * *\end{array}$ & $\begin{array}{l}1.7741 \\
* * *\end{array}$ & $\begin{array}{l}1.7615 \\
* * *\end{array}$ & $\begin{array}{l}1.8455 \\
* * *\end{array}$ & $\begin{array}{l}1.8424 \\
* * *\end{array}$ & $\begin{array}{l}1.9451 \\
* * *\end{array}$ & $\begin{array}{l}1.9911 \\
* * *\end{array}$ \\
\hline Firm age & $\begin{array}{l}-1.4850 \\
* * *\end{array}$ & $\begin{array}{l}-1.4992 \\
* * *\end{array}$ & $\begin{array}{l}-1.2031 \\
* * *\end{array}$ & $\begin{array}{l}-1.4950 \\
* * *\end{array}$ & $\begin{array}{l}-1.5001 \\
* * *\end{array}$ & $\begin{array}{l}-1.5933 \\
* * *\end{array}$ & $\begin{array}{l}-1.5700 \\
* * *\end{array}$ \\
\hline Log sales & $\begin{array}{l}-0.6838 \\
* * *\end{array}$ & $\begin{array}{l}-0.7946 \\
* * *\end{array}$ & $\begin{array}{l}-0.8224 \\
* * *\end{array}$ & $\begin{array}{l}-0.2637 \\
* *\end{array}$ & $\begin{array}{l}-0.2658 \\
* *\end{array}$ & $\begin{array}{l}-0.4771 \\
* * *\end{array}$ & $\begin{array}{l}-0.5128 \\
* * *\end{array}$ \\
\hline Export Intensity (\%) & $\begin{array}{l}0.0376 \\
* * *\end{array}$ & $\begin{array}{l}0.0445 \\
* * *\end{array}$ & $\begin{array}{l}0.0430 \\
* * *\end{array}$ & $\begin{array}{l}0.0483 \\
* * *\end{array}$ & $\begin{array}{l}0.0479 \\
* * *\end{array}$ & $\begin{array}{l}0.0570 \\
* * *\end{array}$ & $\begin{array}{l}0.0550 \\
* * *\end{array}$ \\
\hline Pro-market reform & 0.2521 & 0.3069 & 0.4157 & $\begin{array}{l}0.4702 \\
*\end{array}$ & $\begin{array}{l}0.4859 \\
*\end{array}$ & 0.2279 & 0.2821 \\
\hline $\begin{array}{c}\text { Year dummies } \\
\text { Industry dummies }\end{array}$ & $\begin{array}{l}\text { Included } \\
\text { Included }\end{array}$ & $\begin{array}{l}\text { Included } \\
\text { Included }\end{array}$ & $\begin{array}{l}\text { Included } \\
\text { Included }\end{array}$ & $\begin{array}{l}\text { Included } \\
\text { Included }\end{array}$ & $\begin{array}{l}\text { Included } \\
\text { Included }\end{array}$ & $\begin{array}{l}\text { Included } \\
\text { Included }\end{array}$ & $\begin{array}{l}\text { Included } \\
\text { Included }\end{array}$ \\
\hline Wald Chi-square & $\begin{array}{l}2354.87 \\
* * *\end{array}$ & $\begin{array}{l}2748.66 \\
* * *\end{array}$ & $\begin{array}{l}2133.55 \\
* * *\end{array}$ & $\begin{array}{l}2594.71 \\
* * *\end{array}$ & $\begin{array}{l}2481.93 \\
* * *\end{array}$ & $\begin{array}{l}2779.12 \\
* * *\end{array}$ & $\begin{array}{l}2798.49 \\
* * *\end{array}$ \\
\hline No. of observations & 975 & 975 & 975 & 793 & 793 & 793 & 793 \\
\hline
\end{tabular}

Significance level: * $p<0.10,{ }^{* *} p<0.01, * * * p<0.001$ (two-tailed) 
We find a positive and significant relationship between product diversification and OFDI intensity of Indian EMNEs as tested in Model 1 ( $\beta=1.4284 ; p<0.001)$. These results corroborate extant research of Lu et al., (2014) that prior domestic diversification experience helps firms in their higher commitment mode of internationalization through investing overseas, thereby supporting Hypothesis 1.

Hypothesis 2 suggests a negative moderating effect of family firms on the otherwise positive impact of product diversification on overseas investments. The interaction effects between family firms and product diversification are evident in Model 3. We centered the explanatory variables by their means (Aiken and West, 1991). We find the interaction term to be negative and significant ( $\beta=$ 1.2113; $p<0.001)$; indicating that the effect of product diversification on international investments will be lower for family firms, than in non-family ones. Thus, our results support the arguments of Hypothesis 2. To provide further insights into the moderating effect, we create two plots that compare the interaction effects of family firms and product diversification and that of non-family firms and product diversification on international investments. The line trend in Figure 1 indicates that the positive effect of product diversification on international investments is stronger for non-family firms than for family firms, supporting the arguments of Hypothesis 2.

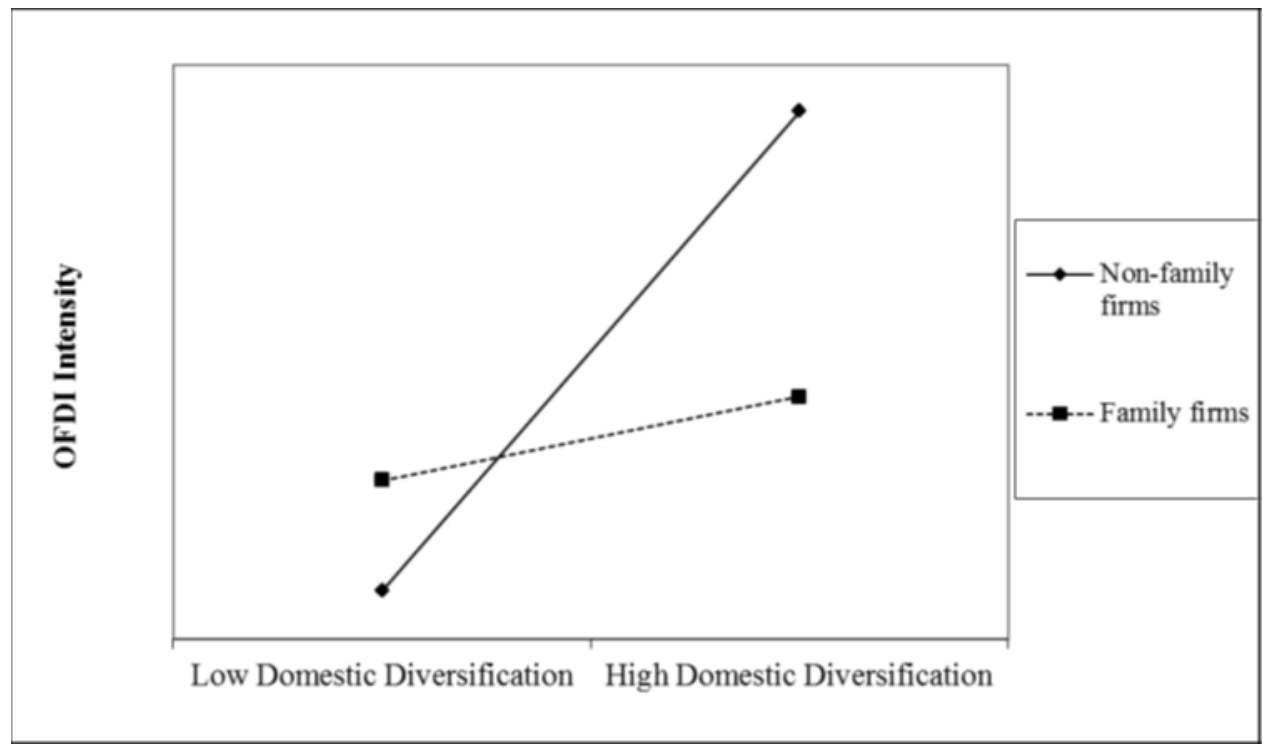

Figure 1. Moderation effect of family ownership on the relationship between domestic diversification and OFDI

Similarly, Hypothesis 3 suggests a negative moderating effect of family-controlled firms on the otherwise positive impact of product diversification on overseas investments. The coefficient of the interaction term is negative and significant $(\beta=-0.1959 ; p<0.10)$; indicating that the effect of product diversification on international investments will be lower for family-controlled firms than familyinfluenced ones. From the graph in Figure 2, we can see that the upward trend of product diversification on OFDI intensity of family firms is lesser for family-controlled firms by virtue of their higher levels of family ownership as compared to those with low levels of family ownership. 


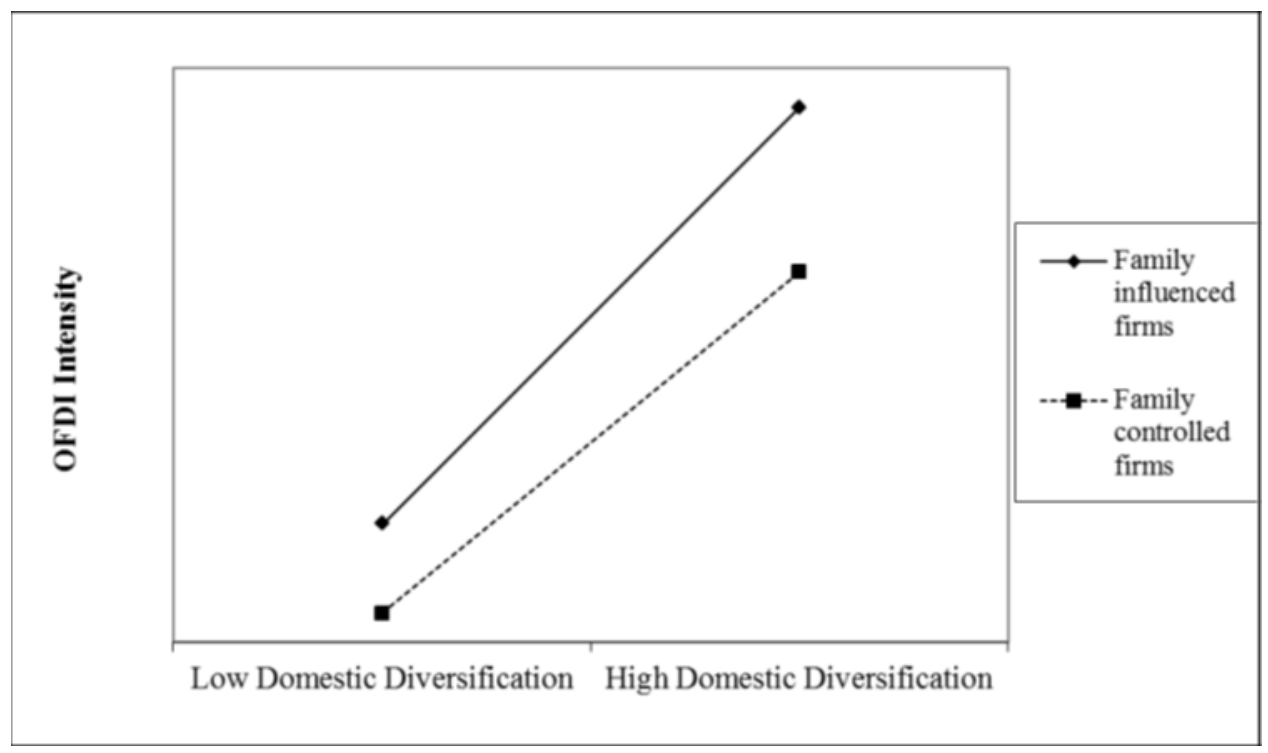

Figure 2. Moderation effect of degree of family control on the relationship between domestic diversification and OFDI

Hypothesis 4 suggests that a positive product diversification - OFDI based internationalization relationship becomes stronger when family firms are affiliated to a family business group. We test this by introducing the interaction term between family business group affiliates and product diversification. The association of the interaction term with OFDI intensity in Model 7 is positive and statistically significant $(\beta=0.2633 ; p<0.01)$. In Figure 3 , the line trend indicates that the positive effect of product diversification and OFDI based internationalization is greater for family business group affiliates than independent family firms, thereby supporting Hypothesis 4 .

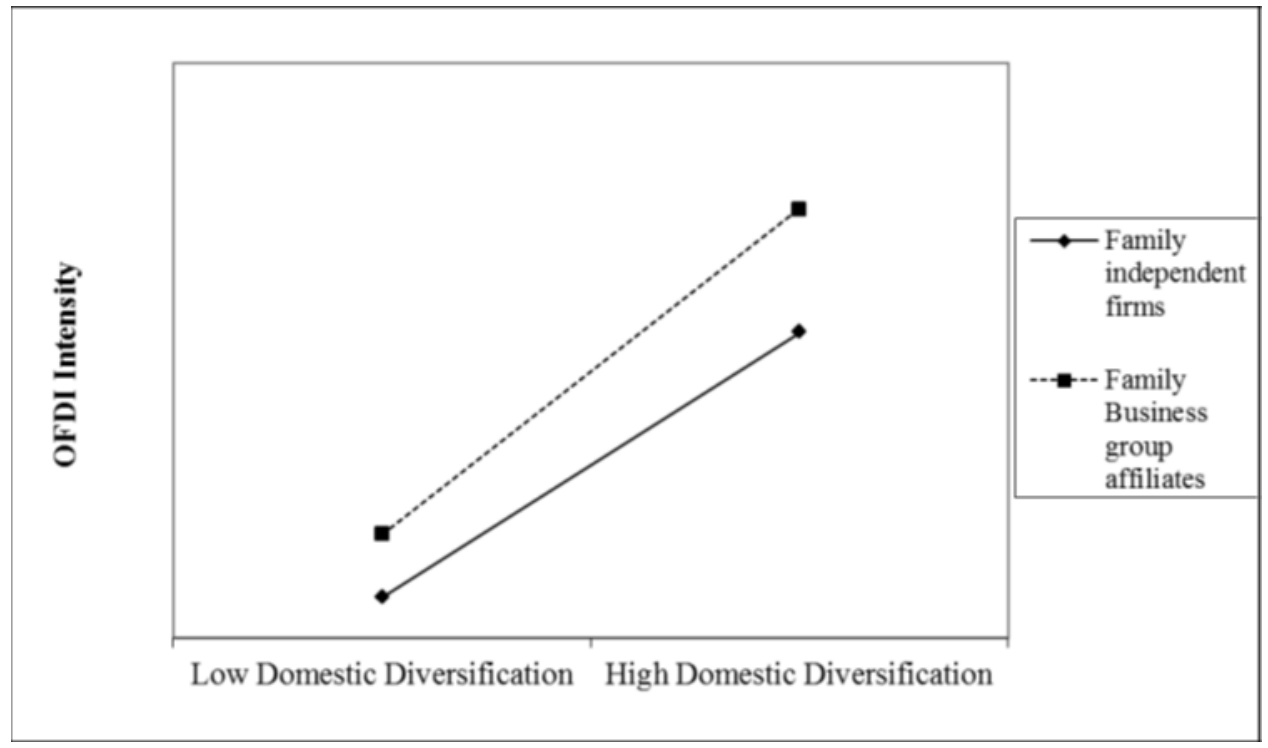

Figure 3. Moderation effect of family business group affiliation on the relationship between domestic diversification and OFDI 


\section{DISCUSSION}

Although the rapid emergence of EMNEs and their increasing shift from exports to OFDI activities has attracted business media attention, scholarly research of their antecedents has only recently evolved (Chittoor et al., 2015; Gubbi et al., 2015). In this study, we examine how operating in their complex and diverse domestic markets can be a vital knowledge resource and capability builder for subsequent OFDI investments. Furthermore, though family firms constitute the majority of publicly listed firms in many emerging economies (anywhere between 35\% and 66\% of listed companies throughout Southeast Asia) (AFBR, 2011), research on such aggressive internationalization of family EMNEs is scant and often limited to exporting activities of small and medium enterprises (De Massis et al., 2018; Pukall and Calabro, 2014; Kontinen and Ojala, 2010). Thus, our study extends the literature on the internationalization of family firms by investigating how the differences between family firms and nonfamily firms, and the heterogeneity within family firms differently moderate the domestic product diversification and OFDI investments relationship.

First, we demonstrate that EMNEs that have developed the capability to integrate market intelligence and comprehensive knowledge from its channel partners, suppliers, and customers across its various product offerings in the domestic market are more likely to be on aggressive OFDI based internationalization trajectories. Large and diverse countries such as India house heterogeneous populations not just across various regions, but even within cities and regions, and therefore, firms have to offer multiple products to satisfy these diverse customer segments. When firms operate in multiple product markets, they create structures to integrate and improve the efficiency of information and knowledge flows within the organization, and these organization-specific integrative capabilities are important for the development of productive capabilities (Low and Ho, 2016). Since EMNEs are 'latecomers' as compared to MNEs from developed countries, the knowledge gained through extensive domestic operations in complex and dynamic emerging economies is likely to overcome some of the disadvantages of inexperience in international operations, leading to greater OFDI undertaken by them. It is also a firm-specific advantage because this knowledge is internal and there is causal ambiguity because of which it cannot be easily imitated by other firms (Rugman and Sukpanich, 2006).

Our results corroborate the extant literature on the importance of prior learning from domestic markets in enabling internationalization (Batsakis and Mohr, 2017; Mayer et al., 2015, Lu et al., 2014), and extends these studies to elucidate the importance of product-market diversification on the international investments of Indian EMNEs. The results from our study suggest that EMNEs that had undertaken extensive product diversification are more adept at investing abroad. By studying exports, a low commitment mode, as a mode of internalization, prior studies have examined industrial diversification over product diversification (Lu et al., 2014). Hence, the research does not factor in the complexities and risks of operations in a foreign country. Moreover, Mayer et al., (2015) and Kumar (2009) examine the impact of the short-term resource constraints on growth strategies. OFDI, however, is not a short-term growth strategy of the EMNE. It requires a significant commitment of resources, managerial effort, and attention, and is difficult to reverse. Through this study, we also detail the unique ownership advantages that EMNEs from large and diverse countries such as India possess, supporting the arguments of Ramamurti (2012) and Peng (2012).

Second, based on our findings, we demonstrate that though knowledge is an important and necessary condition, its usage is contingent on many factors. We argue and provide evidence for family ownership as an important complementary condition that affects firms' ability to deploy their domestic experience in their international operations. By using SEW preservation as the frame of 
reference for strategic decisions, family firm owners and managers do not link the various strategic concepts derived from the complexity of knowledge to which they are exposed (Nadkarni and Perez, 2007). Top managers' mindset influences strategic decision-making through scanning, diagnosis, and choice of alternatives (Weick, 1995). Even if family firm owners and managers scan the environment thoroughly and diagnose the challenges they are likely to face, SEW considerations restrict the choice of alternatives. They are unlikely to consider options that would require the family to cede control either in the form of ownership, or management in order to obtain additional resources (Gomez-Mejia et al., 2010). Hence, the family firms deploy a simple mindset, which reduces their ability to leverage knowledge structures from domestic to international markets.

However, heterogeneity in family firm ownership leads to variations in their capabilities to exploit knowledge (Chua et al., 2012; Fang et al., 2018; Williams et al., 2018). In family-influenced firms, the family has already ceded ownership to external parties in exchange for resources and expertise (Arregle et al., 2012), therefore, preservation of SEW is no longer the primary objective. Moreover, the resources and expertise of non-family owners supplement the knowledge base of the family firm (Ray et al., 2018). This augmented knowledge base and resources enhance the scanning and diagnostic abilities of the decision-makers. Access to resources and decrease in priority accorded to SEW considerations increases the choice of alternatives. Hence, decreasing family ownership concentration augments the ability of the family firm to exploit the knowledge to expand internationally through OFDI. We thus, extend the extant literature that has demonstrated generation differences in family firms (Fang et al., 2018), TMT characteristics (Lu et al., 2014) and international experience (Mayer et al. 2015; Kumar et al, 2012) as important complements to the ability of EMNEs to leverage their knowledge-based resources.

Third, we contribute to the literature on heterogeneity in family firms (Chua et al., 2012; Williams et al., 2018) by examining affiliation to family business groups as another source of variation in their strategic decisions. Although Purkayastha et al., (2018), and Purkayastha et al., (2017) examine the role of family ownership in business groups, their focus is on evaluating business group heterogeneity. In this paper, we extend the literature that examines the differences between the strategic decisions of family firms affiliated to a family business group and independent family firms (Choi et al., 2015) in the context of international expansion through OFDI. There is extensive literature that has documented the role of internal capital and labor markets and the support extended to affiliate firms from other firms in the business group network that impacts the firm's strategic decisions (Kumar et al., 2020; Purkayastha et al., 2018; Chittoor et al., 2009). Family firms that are part of the business group structure do not have to rely on external sources for resources, knowledge, or expertise, extensively. The shared ownership and the need to provide growth opportunities for family members motivate knowledge sharing as well as access to funding that can promote international expansion through OFDI (Gu et al., 2019; Ayyagari et al., 2015). These additional resources attenuate the risk aversion and considerations of the preservation of SEW. They also help the firm in overcoming constraints imposed by the simultaneous growth in product and international diversification. Thus, the complexity of the mindset of managers of family business group affiliates increases and amplifies the firm's ability to exploit its product diversification knowledge to expand internationally through OFDI. 


\section{LIMITATIONS}

While we make many contributions to literature, our study has limitations that allow for future research. Given that we have investigated only large firms of Indian origin, we advocate more research on similar lines with diverse samples that include SMEs from developed as well as emerging economies. We use measures of the family business in consonance with extant literature (Singla et al., 2014). Yet, finer grained measures of family ownership that reflect the heterogeneity of family businesses could also result in a more nuanced understanding of family-governed multinationals. We also use proxies for integrative capabilities, the complexity of domestic mindset, and SEW. Subsequent studies could measure these constructs and test the mechanism directly. We also call for greater crossfertilization of research ideas among two streams of scholars, one focusing on EMNEs and the other on internationalization of family firms.

\section{CONCLUSION}

We use a novel dataset of the large Indian family and non-family EMNEs and investigate their international expansion decisions to generate unique conceptual and empirical insights. More specifically, we investigate whether knowledge gained from home country markets abets or hinders EMNEs' international expansion through OFDI. We also examine the contingent effect of family ownership and the heterogeneity within family firms on this relationship between knowledge gained from home markets and decisions to expand internationally. We found that product-market diversification aids firms in internationalization through OFDI. We demonstrated that family firms and family firms with concentrated ownership constrain the application of knowledge gained from domestic markets to expand internationally through OFDI. However, resources gained by being a part of family business groups enhance this relationship. Future studies could extend our investigation by focusing on other aspects of family firm heterogeneity, and additional sources of advantages of operating in prominent EMNEs like those in India.

\section{ACKNOWLEDGEMENT}

We thank the anonymous reviewers for their constructive comments on earlier versions of the article. We would also like to thank the editor Prof. Kamal Upadhyaya for his encouraging feedback and support throughout the review and publication process. 


\section{REFERENCES}

Aiken, L.S. and West, S.G. (1991). Multiple Regression: Testing and Interpreting Interactions. Sage Publications, Newbury Park.

Ambos, T. C., and Ambos, B. (2009). The impact of distance on knowledge transfer effectiveness in multinational corporations. Journal of International Management, 15(1), 1-14.

Arregle, J. L., Naldi, L., Nordqvist, M., and Hitt, M. A. (2012). Internationalization of family-controlled firms: A study of the effects of external involvement in governance. Entrepreneurship Theory and Practice, 36(6), 1115-1143.

Asian Family Businesses Report (AFBR) (2011) Asia is China, India, South Korea, Hong Kong, Taiwan, Thailand, the Philippines, Malaysia, Singapore, and Indonesia, Credit Suisse Emerging Market Research Institute.

Ayyagari, M., Dau, L. A., and Spencer, J. (2015). Strategic responses to FDI in emerging markets: Are core members more responsive than peripheral members of business groups?. Academy of Management Journal, 58(6), 1869-1894.

Barkema, H.G., Bell, J.H. and Pennings, J.M., (1996). Foreign entry, cultural barriers, and learning. Strategic Management Journal, 17(2), pp.151-166.

Bartlett, C. G., and Ghoshal, S. S. (1989): Managing Across Borders: The Transnational Solution. Harvard Business School Press, Boston, MA.

Baskaran, A., Liu, J., Yan, H., and Muchine, M. (2017). Outward Foreign Direct Investment (OFDI) \& Knowledge Flow in the Context of Emerging MNEs: Cases from China, India and South Africa. African Journal of Science, Technology Innovation and Development, 9(5), pp-539-555.

Basu, N., Dimitrova, L., and Paeglis, I. (2009). Family control and dilution in mergers. Journal of Banking \& Finance, 33(5), 829-841.

Batsakis, G., and Mohr, A. T. (2017). Revisiting the relationship between product diversification and internationalization process in the context of emerging market MNEs. Journal of World Business, 52(4), 564-577.

BCG (2013). Introducing the 2013 BCG Global Challengers. https://www.bcg.com/engb/publications/2013/globalization-growth-introducing-2013-bcg-global-challengers.aspx. Retrieved on 10-Jan-2020.

Beck, N., and Katz, J. N. (1995). What to do (and not to do) with time-series cross-section data. American Political Science Review, 89(03), 634-647.

Berrone, P., Cruz, C., Gomez-Mejia, L. R., and Larraza-Kintana, M. (2010). Socioemotional wealth and corporate responses to institutional pressures: Do family-controlled firms pollute less? Administrative Science Quarterly, 55(1), 82-113.

Berrone, P., Cruz, C., and Gómez-Mejía, L. R. (2012). Socioemotional wealth in family firms theoretical dimensions, assessment approaches, and agenda for future research. Family Business Review, 25(3), 258-279.

Bharti Airtel. (2010). Annual Report. https://s3-ap-southeast-

1.amazonaws.com/bsy/iportal/images/Bharti_Airtel_Annual_Report_2009_10_497358E9836C 9820191EC4872AA80920.pdf. Accessed on May 12, 2020.

Bhaumik, S. K., Driffield, N., and Pal, S. (2010). Does ownership structure of emerging-market firms affect their outward FDI \& quest: The case of the Indian automotive and pharmaceutical sectors. Journal of International Business Studies, 41(3), 437-450.

Borda, A., Geleilate, J. M. G., Newburry, W., and Kundu, S. K. (2017). Firm internationalization, business group diversification and firm performance: The case of Latin American firms. Journal of Business Research, 72, 104-113. 
Carney, M. (2005). Corporate governance and competitive advantage in family-controlled firms. Entrepreneurship Theory and Practice, 29(3), 249-265.

Chandler, A. D. (1990). Strategy and structure: Chapters in the history of the industrial enterprise (Vol. 120). MIT press.

Chari, M. D. (2013). Business groups and foreign direct investments by developing country firms: An empirical test in India. Journal of World Business, 48(3): 349-359.

Chen, H. L., Hsu, W. T., and Chang, C. Y. (2016). Independent directors' human and social capital, firm internationalization and performance implications: An integrated agency-resource dependence view. International Business Review, 25(4), 859-871.

Child, J., and Rodrigues, S. B. (2005). The Internationalization of Chinese Firms: A Case for Theoretical Extension? 1. Management and Organization Review, 1(3), 381-410.

Chittoor, R., Sarkar, M. B., Ray, S., and Aulakh, P. S. (2009). Third-world copycats to emerging multinationals: Institutional changes and organizational transformation in the Indian pharmaceutical industry. Organization Science, 20(1), 187-205.

Chittoor, R., Aulakh, P. S., and Ray, S. (2015). Accumulative and assimilative learning, institutional infrastructure, and innovation orientation of developing economy firms. Global Strategy Journal, 5(2), 133-153.

Choi, Y. R., Zahra, S. A., Yoshikawa, T., and Han, B. H. (2015). Family ownership and R\&D investment: The role of growth opportunities and business group membership. Journal of Business Research, 68(5), 1053-1061.

Chrisman, J. J., Chua, J. H., and Steier, L. (2005). Sources and consequences of distinctive familiness: An introduction. Entrepreneurship Theory and Practice, 29(3), 237-247.

Chua, J. H., Chrisman, J. J., Steier, L. P., and Rau, S. B. (2012). Sources of Heterogeneity in Family Firms: An Introduction. Entrepreneurship Theory and Practice, 36(6), 1103-1113.

Chung, H. M. (2013). The role of family management and family ownership in diversification: The case of family business groups. Asia Pacific Journal of Management, 30(3), 871-891.

Claver, E., Rienda, L., and Quer, D. (2009). Family firms' international commitment: The influence of family-related factors. Family Business Review, 22(2), 125-135.

Cohen, W. M., and Levinthal, D. A. (1990). Absorptive capacity: A new perspective on learning and innovation. Administrative Science Quarterly, 35(1), 128-152.

Cuervo-Cazurra, A., and Genc, M. (2008). Transforming disadvantages into advantages: developingcountry MNEs in the least developed countries. Journal of International Business Studies, 39(6), 957-979.

Dau, L. A. (2012). Pro-market reforms and developing country multinational corporations. Global Strategy Journal, 2(3), 262-276.

De Massis, A., Kotlar, J., and Frattini, F. (2013). Is social capital perceived as a source of competitive advantage or disadvantage for family firms? An exploratory analysis of CEO perceptions. The Journal of Entrepreneurship, 22(1), 15-41.

De Massis, A., Frattini, F., Majocchi, A., and Piscitello, L. (2018). Family firms in the global economy: Toward a deeper understanding of internationalization determinants, processes, and outcomes. Global Strategy Journal, 8(1), 3-21.

Deng, P. (2013). Chinese outward direct investment research: Theoretical integration and recommendations. Management and Organization Review, 9(3), 513-539.

Dheer, R. J., Lenartowicz, T., and Peterson, M. F. (2015). Mapping India's regional subcultures: Implications for international management. Journal of International Business Studies, 46(4), 443-467. 
Fang, H., Kotlar, J., Memili, E., Chrisman, J. J., and De Massis, A. (2018). The pursuit of international opportunities in family firms: Generational differences and the role of knowledge-based resources. Global Strategy Journal, 8(1), 136-157.

Family Firm Institute. (2017). Global Data Points. Retrieved from the https://perma.cc/CF89-K2JB website on May 06, 2020: http://www.ffi.org/page/globaldatapoints.

Fernández-Aráoz, C., Iqbal, S., and Ritter, J. (2015). Leadership lessons from great family businesses. Harvard Business Review, 93(4), 20.

Fisman, R. (2001). Estimating the value of political connections. American Economic Review, 91(4), 10951102.

Gadepalli, S. D., and Mondal, A. (2018). Sources of Business Unit Performance Heterogeneity in India: The Influence of Ownership. Vikalpa, 43(4), 207-221.

Gaur, A. S., and Kumar, V. (2009). International diversification, business group affiliation and firm performance: Empirical evidence from India. British Journal of Management, 20(2), 172-186.

Gaur A. S., Kumar, V. and Singh, D. A. (2014). Resources, institutions and internationalization process of emerging economy firms. Journal of World Business, 49: 12-20.

Gaur, A. S., Ma, X., and Ding, Z. (2018). Home country supportiveness/unfavorableness and outward foreign direct investment from China. Journal of International Business Studies, 49(3), 324-345.

Ghemawat, P. (2001). Distance still matters. Harvard Business Review, 79(8), 137-147.

Giesen, E., Berman, S. J., Bell, R., and Blitz, A. (2007). Three ways to successfully innovate your business model. Strategy \& Leadership, 35(6), 27-33.

Gómez-Mejía, L.R., Nunez-Nickel, M. and Gutierrez, I., (2001). The role of family ties in agency contracts. Academy of Management Journal, 44(1), pp.81-95.

Gómez-Mejía, L. R., Haynes, K. T., Núñez-Nickel, M., Jacobson, K. J. L., and Moyano-Fuentes, J. (2007). Socioemotional wealth and business risks in family controlled firms: Evidence from Spanish olive oil mills. Administrative Science Quarterly, 52, 106-137.

Gómez-Mejía, L.R., Makri, M. and Kintana, M.L., (2010). Diversification decisions in family-controlled firms. Journal of Management Studies, 47(2), pp.223-252.

Gómez-Mejía, L. R., Cruz, C., Berrone, P., and De Castro, J. (2011). The bind that ties: Socioemotional wealth preservation in family firms. Academy of Management Annals, 5, 653-707

Granovetter, M. (2005). The impact of social structure on economic outcomes. Journal of Economic Perspectives, 19(1), 33-50.

Grant, R. M. (1996). Toward a knowledge-based theory of the firm. Strategic Management Journal, $17(\mathrm{~S} 2), 109-122$.

Grosse, R., and Trevino, L. J. (1996). Foreign direct investment in the United States: An analysis by country of origin. Journal of International Business Studies, 27(1), 139-155.

Gu, Q., Lu, J. W., and Chung, C. N. (2019). Incentive or disincentive? A socioemotional wealth explanation of new industry entry in family business groups. Journal of Management, 45(2), 645-672.

Gubbi, S. R., Aulakh, P. S., and Ray, S. (2015). International search behavior of business group affiliated firms: Scope of institutional changes and intragroup heterogeneity. Organization Science, 26(5), 1485-1501.

Guillén, M. F. (2002). Structural inertia, imitation, and foreign expansion: South Korean firms and business groups in China, 1987-1995. Academy of Management Journal, 45(3), 509-525.

Habbershon, T. G., and Williams, M. L. (1999). A resource-based framework for assessing the strategic advantages of family firms. Family Business Review, 12(1), 1-25.

Hernández, V., Nieto, M. J., and Boellis, A. (2018). The asymmetric effect of institutional distance on international location: Family versus nonfamily firms. Global Strategy Journal, 8(1), 22-45. 
Herrmann, P., and Datta, D. K. (2005). Relationships between top management team characteristics and international diversification: An empirical investigation. British Journal of Management, 16(1), 69-78.

Howorth, C., Rose, M., and Hamilton, E. (2006). Definitions, diversity and development: Key debates in family business research. The Oxford Handbook of Entrepreneurship, 225-47.

Hitt, M. A., Hoskisson, R. E., and Kim, H. (1997). International diversification: Effects on innovation and firm performance in product-diversified firms. Academy of Management Journal, 40(4), 767798.

Hu, H. W., and Cui, L. (2014). Outward foreign direct investment of publicly listed firms from China: A corporate governance perspective. International Business Review, 23(4), 750-760.

lurkov, V., and Benito, G. R. (2018). Domestic alliance networks and regional strategies of MNEs: A structural embeddedness perspective. Journal of International Business Studies, 49(8), 10331059.

James, H. S. (1999). Owner as manager, extended horizons and the family firm. International Journal of the Economics of Business, 6(1), 41-55.

Johanson, J., and Vahlne, J. E. (1977). The internationalization process of the firm: A model of knowledge development and increasing foreign market commitment. Journal of International Business Studies, 8(1): 23-32.

Khanna, T., and Palepu, K. (2000). Is group affiliation profitable in emerging markets? An analysis of diversified Indian business groups. Journal of Finance, 55(2): 867-891.

Khanna, T., and Rivkin, J. W. (2001). Estimating the performance effects of business groups in emerging markets. Strategic Management Journal, 22(1), 45-74.

Kogut, B., and Zander, U. (1992). Knowledge of the firm, combinative capabilities, and the replication of technology. Organization Science, 3(3), 383-397.

Kogut, B., and Zander, U. (1993). Knowledge of the firm and the evolutionary theory of the multinational corporation. Journal of International Business Studies, 24(4), 625-645.

Kontinen, T., and Ojala, A. (2010). The internationalization of family businesses: A review of extant research. Journal of Family Business Strategy, 1, 97-107.

Kumar, M.S., 2009. The relationship between product and international diversification: The effects of short-run constraints and endogeneity. Strategic Management Journal, 30(1), pp.99-116.

Kumar, V., Jones, E., Venkatesan, R., and Leone, R. P. (2011). Is market orientation a source of sustainable competitive advantage or simply the cost of competing?. Journal of marketing, 75(1), 16-30.

Kumar, V., Gaur, A. S., and Pattnaik, C. (2012). Product diversification and international expansion of business groups. Management International Review, 52(2), 175-192.

Kumar, V., Singh, D., Purkayastha, A., Popli, M., and Gaur, A. (2020). Springboard internationalization by emerging market firms: Speed of first cross-border acquisition. Journal of International Business Studies, 51(2), 172-193.

La Porta, R., Lopez-de-Silanes, F., Shleifer, A., and Vishny, R. (1999). The quality of government. Journal of Law, Economics, and Organization, 15(1), 222-279.

Lee S-H, Makhija M, Paik Y. 2008. The value of real options investments under abnormal uncertainty: the case of the Korean economic crisis. Journal of World Business, 44: 1-15.

Lee, H. U., and Park, J. H. (2008). The influence of top management team international exposure on international alliance formation. Journal of Management Studies, 45(5), 961-981.

Le Breton-Miller, I., Miller, D., and Lester, R. H. (2011). Stewardship or agency? A social embeddedness reconciliation of conduct and performance in public family businesses. Organization Science, 22(3), 704-721. 
Lenovo. (2014). Lenovo Set to Close Acquisition of IBM's x86 Server Business. https://news.lenovo.com/pressroom/press-releases/lenovo-set-to-close-acquisition-ibms-x86server-business/ Accessed on May 12, 2020.

Liu, X., and Buck, T. (2009). The internationalisation strategies of Chinese firms: Lenovo and BOE. Journal of Chinese Economic and Business Studies, 7(2), 167-181.

Low, K. Y. J., and Ho, E. Y. C. (2016). A knowledge-based theory of the multinational economic organization. Long Range Planning, 49(6), 641-647.

Lu, J. W., and Beamish, P. W. (2001). The internationalization and performance of SMEs. Strategic Management Journal, 22(6-7), 565-586.

Lu, J., Liu, X., Filatotchev, I., and Wright, M. (2014). The impact of domestic diversification and top management teams on the international diversification of Chinese firms. International Business Review, 23(2), 455-467.

Luo, Y., and Tung, R. L. (2007). International expansion of emerging market enterprises: A springboard perspective. Journal of International Business Studies, 38: 481-498.

Luo, Y., and Tung, R. L. (2018). A general theory of springboard MNEs. Journal of International Business Studies, 49(2), 129-152.

Madhok, A., and Keyhani, M. (2012). Acquisitions as entrepreneurship: Asymmetries, opportunities, and the internationalization of multinationals from emerging economies. Global Strategy Journal, 2(1), 26-40.

Makino, S., Isobe, T., and Chan, C. M. (2004). Does country matter?. Strategic Management Journal, 25(10), 1027-1043.

Masulis, R. W., Pham, P. K., and Zein, J. (2011). Family business groups around the world: Financing advantages, control motivations, and organizational choices. The Review of Financial Studies, 24(11), 3556-3600.

Mayer, M.C., Stadler, C. and Hautz, J. (2015). The relationship between product and international diversification: The role of experience. Strategic Management Journal, 36(10), pp.1458-1468.

McConaughy, D. L., Matthews, C. H., and Fialko, A. S. (2001). Founding family controlled firms: Performance, risk, and value. Journal of Small Business Management, 39(1), 31-49.

Meyer, K. E., and Grosse, R. (2018). Introduction to managing in emerging markets. Oxford handbook of managing in emerging markets, 3-34.: Oxford University Press. Retrieved 12 May. 2020, from https://www.oxfordhandbooks.com/view/10.1093/oxfordhb/9780190683948.001.0001/oxford hb-9780190683948-e-1.

Montgomery, C. A. (1982). The measurement of firm diversification: Some new empirical evidence. Academy of Management Journal, 25(2), 299-307.

Morck, R. and Yeung, B. (2003). Agency problems in large family business groups. Entrepreneurship Theory and Practice, 27(4), pp.367-382.

Nadkarni, S., and Perez, P. D. (2007). Prior conditions and early international commitment: The mediating role of domestic mindset. Journal of International Business Studies, 38(1), 160-176.

Nadkarni, S., Herrmann, P., and Perez, P. D. (2011). Domestic mindsets and early international performance: The moderating effect of global industry conditions. Strategic Management Journal, 32(5), 510-531.

Nahapiet, J., and Ghoshal, S. (1998). Social capital, intellectual capital, and the organizational advantage. Academy of Management Review, 23(2), 242-266.

Nath, P., Nachiappan, S., and Ramanathan, R. (2010). The impact of marketing capability, operations capability and diversification strategy on performance: A resource-based view. Industrial Marketing Management, 39(2), 317-329. 
Narula, R., and Kodiyat, T. P. (2016). How weaknesses in home country location advantages can constrain EMNE growth: the example of India. Multinational Business Review, 24(3), 249-278.

Paul, J., and Benito, G. R. (2018). A review of research on outward foreign direct investment from emerging countries, including China: what do we know, how do we know and where should we be heading?. Asia Pacific Business Review, 24(1), 90-115.

Peng, M. W. (2012). The global strategy of emerging multinationals from China. Global Strategy Journal, 2(2), 97-107.

Pukall, T. J., and Calabrò, A. (2014). The Internationalization of Family Firms A Critical Review and Integrative Model. Family Business Review, 27(2), 103-125.

Purkayastha, S., Kumar, V., and Lu, J. W. (2017). Business group heterogeneity and the internationalization-performance relationship: Evidence from Indian business groups. Asia Pacific Journal of Management, 34(2), 247-279.

Purkayastha, S., Manolova, T. S., and Edelman, L. F. (2018). Business group effects on the R\&D intensity-internationalization relationship: Empirical evidence from India. Journal of World Business, 53(2), 104-117.

Ramamurti, R. (2012). What is really different about emerging market multinationals?. Global Strategy Journal, 2(1), 41-47.

Ray, S., Mondal, A., and Ramachandran, K. (2018). How does family involvement affect a firm's internationalization? An investigation of Indian family firms. Global Strategy Journal, 8(1), 73105.

Reuters. (2013). Thai billionaire Charoen builds empire with F\&N takeover. https://www.reuters.com/article/us-fraserandneave-billionaire/thai-billionaire-charoen-buildsempire-with-fn-takeover-idUSBRE9oL05W20130122. Accessed on May 12, 2020.

Rugman, A., and Sukpanich, N. (2006). Firm-specific advantages intra-regional sales and performance of multinational enterprises. The International Trade Journal, 20(3), 355-382.

Sahay, M. R., and Goyal, R. (2006). Volatility and growth in Latin America: an episodic approach (No. 6287). International Monetary Fund.

Sharma, P., and Chua, J. H. (2013). Asian family enterprises and family business research. Asia Pacific Journal of Management, 30(3), 641-656.

Singh, D. A., and Gaur, A. S. (2009). Business group affiliation, firm governance, and firm performance: Evidence from China and India. Corporate Governance: An International Review, 17(4), 411-425.

Singla, C., Veliyath, R., and George, R. (2014). Family firms and internationalization-governance relationships: Evidence of secondary agency issues. Strategic Management Journal, 35(4), 606616.

Sirmon, D. G., Arregle, J. L., Hitt, M. A., and Webb, J. W. (2008). The role of family influence in firms' strategic responses to threat of imitation. Entrepreneurship Theory and Practice, 32(6), 979998.

Schulze, W. S., Lubatkin, M. H., and Dino, R. N. (2002). Altruism, agency, and the competitiveness of family firms. Managerial and Decision Economics, 23(45), 247-259.

Stoian, C., and Mohr, A. (2016). Outward foreign direct investment from emerging economies: Escaping home country regulative voids. International Business Review, 25(5), 1124-1135.

Tang, C., Tang, Y., and Su, S. (2019). R\&D internationalization, product diversification and international performance for emerging market enterprises: An empirical study on Chinese enterprises. European Management Journal, 37(4), 529-539.

The Economist. (2011). Out of India. https://www.economist.com/briefing/2011/03/03/out-of-india Accessed on May 12, 2020. 
Tihanyi, L., Ellstrand, A. E., Daily, C. M., and Dalton, D. R. (2000). Composition of the top management team and firm international diversification. Journal of Management, 26(6), 1157-1177.

Tihanyi, L., Johnson, R. A., Hoskisson, R. E., and Hitt, M. A. (2003). Institutional ownership differences and international diversification: The effects of boards of directors and technological opportunity. Academy of Management Journal, 46(2), 195-211.

UNCTAD (2016). World Investment Report. https://unctad.org/en/PublicationsLibrary/wir2016_en.pdf. Accessed on May 06, 2020

UNCTAD (2019). World Investment Report. https://unctad.org/en/PublicationsLibrary/wir2019_en.pdf. Accessed on November 11, 2019.

Williams Jr, R. I., Pieper, T. M., Kellermanns, F. W., and Astrachan, J. H. (2018). Family firm goals and their effects on strategy, family and organization behavior: A review and research agenda. International Journal of Management Reviews, 20, S63-S82.

Weick, K.E. (1995), Sensemaking in Organizations, London, Sage.

Westhead, P., and Howorth, C. (2007). 'Types' of private family firms: an exploratory conceptual and empirical analysis. Entrepreneurship and Regional Development, 19(5), 405-431.

Wright, M., Chrisman, J. J., Chua, J. H., and Steier, L. P. (2014). Family Enterprise and Context. Entrepreneurship Theory and Practice, 38(6), 1247-1260. https://doi.org/10.1111/etap.12122

Zahavi, T., and Lavie, D. (2013). Intra-industry diversification and firm performance. Strategic Management Journal, 34(8), 978-998

Zahra, S. A. (2003). International expansion of U.S. manufacturing family businesses: The effect of ownership and involvement. Journal of Business Venturing, 18, 495-512.

Zattoni, A., Pedersen, T., and Kumar, V. (2009). The performance of group-affiliated firms during institutional transition: A longitudinal study of Indian firms. Corporate Governance: An International Review, 17(4), 510-523.

Zellweger, T. M., Kellermanns, F. W., Chrisman, J. J., and Chua, J. H. (2012). Family control and family firm valuation by family CEOs: The importance of intentions for transgenerational control. Organization Science, 23(3), 851-868.

Zellweger, T. M., Nason, R. S., Nordqvist, M., and Brush, C. G. (2013). Why do family firms strive for nonfinancial goals? An organizational identity perspective. Entrepreneurship Theory and Practice, 37(2), 229-248. 